\title{
Re-Evaluation of Kombat-Style Mineralization and Implications for Exploration in the Otavi Mountainland, Namibia
}

\author{
Abner Nghoongoloka ${ }^{1,2}$, Rob Bowell ${ }^{3}$, Fred Kamona ${ }^{2}$, Helke Mocke ${ }^{1}$ \\ ${ }^{1}$ Department of Geological Survey of Namibia (GSN), Ministry of Mines and Energy, Windhoek, Namibia \\ ${ }^{2}$ Departmentof Geology, University of Namibia (UNAM), Windhoek, Namibia \\ ${ }^{3}$ Department of Earth Science Miller Hall, Queens University, Kingston, Canada \\ Email: *Abner.Nghoongoloka@mme.gov.na
}

How to cite this paper: Nghoongoloka, A., Bowell, R., Kamona, F. and Mocke, H. (2020) Re-Evaluation of Kombat-Style Mineralization and Implications for Exploration in the Otavi Mountainland, Namibia. Open Journal of Geology, 10, 1119-1152.

https://doi.org/10.4236/ojg.2020.1011054

Received: October 12, 2020

Accepted: November 27, 2020

Published: November 30, 2020

Copyright (c) 2020 by author(s) and Scientific Research Publishing Inc. This work is licensed under the Creative Commons Attribution International License (CC BY 4.0).

http://creativecommons.org/licenses/by/4.0/

(c) (i) Open Access

\begin{abstract}
This study re-evaluates the characteristics of $\mathrm{Cu}-\mathrm{Pb}-\mathrm{Ag}$ and $\mathrm{Fe}-\mathrm{Mn}$ ore mineralization of the Kombat Mine and Gross Otavi Mine based on field geology, fluid inclusions, petrology, mineralogy, and geochemistry. This is to determine the genetic relationship between $\mathrm{Fe}-\mathrm{Mn}$ and $\mathrm{Cu}-\mathrm{Pb}-\mathrm{Ag}$ mineralization. The study has established that the $\mathrm{Cu}-\mathrm{Pb}-\mathrm{Ag}$ ore at the Kombat Mine can be classified as a variant of MVT-type deposit, whereas the Fe-Mn ore can be classified as a stratiform-syn-sedimentary deposit. The formation of the MVT-type deposit is associated with a hydrothermal fluid system with a mean temperature of $183^{\circ} \mathrm{C}$ and mean salinity of $12.85 \mathrm{wt} . \% \mathrm{NaCl}$ equivalent. The syn-sedimentary Fe-Mn ore, which is largely associated with calc-silicate lithologies, consists mainly of magnetite and hematite with minor pyrite, hausmannite and jacobsite, and was deposited by diagenetic and mixed diagenetic-hydrogenetic processes under changing oxic and anoxic conditions within the sedimentary basin. Acceptable geochemical exploration indicators of the existing mineralization include anomalous values above $0.5 \% \mathrm{Cu}, 0.2 \% \mathrm{~S} ; 0.05 \% \mathrm{~Pb} ; 0.04 \% \mathrm{As} ; 0.01 \% \mathrm{Zn} ; \mathrm{V}, \mathrm{W}, \mathrm{Mo}$, and $\mathrm{Ag}$ are $0.002 \%$. Mineralogical indicators include chalcopyrite, bornite, covellite and galena with minor chalcocite, sphalerite, and tennantite for the $\mathrm{Cu}-\mathrm{Pb}$ MVT-type ores at Kombat Mine.
\end{abstract}

\section{Keywords}

MVT-Type Deposit, Hydrothermal, Syn-Sedimentary, Genetic Model, Exploration 


\section{Introduction}

The Kombat Mine is one of the most significant copper mines in Namibia. It originally commenced mining in 1962 and operated until 2008, producing 12.5 million tonnes of ore grading 2.6\% Cu over this period [1] [2]. Six defined ore blocks have been delineated to date that are collectively termed Kombat Mine and are located on the northern limb of the canoe-shaped, doubly plunging Otavi Valley Synclinorium, in the contact zone between phyllite of the Kombat Formation and underlying dolomites of the upper Tsumeb Subgroup (Figure 1). This extends for over $4 \mathrm{~km}$ [3]. The mine is unique in the Otavi Mountainland $(\mathrm{OML})$ in that the base metal hosting massive and semi-massive sulfides, fracture veins and galena-rich alteration breccias are spatially associated with replacement iron-manganese oxide/silicate mineralization that hosts several unique minerals first described at Kombat Mine [4].

The unusual mineral association of the Kombat-style mineralization warrants a re-evaluation of the genetic relationship between iron-manganese and copper-lead silver ores.

Kombat-style mineralization was first reported by Sir Francis Galton in 1851 [1]. From 1909 and 1911, the historic Gross Otavi and the Kombat Mines, respectively, were exploited by the OtaviMinen- und Eisenbahn-Gesellschaft (OMEG) until 1925 when groundwater ingress shut down both mines [4]. The operations included limited surface production and underground mining at both Kombat and Gross Otavi. Operations restarted in 1962 and worked continuously until 2008, when the underground Kombat Mine was shut down following a flooding incident and depressed global base metal prices [5].

The existing resources estimates were based on series of exploration activities

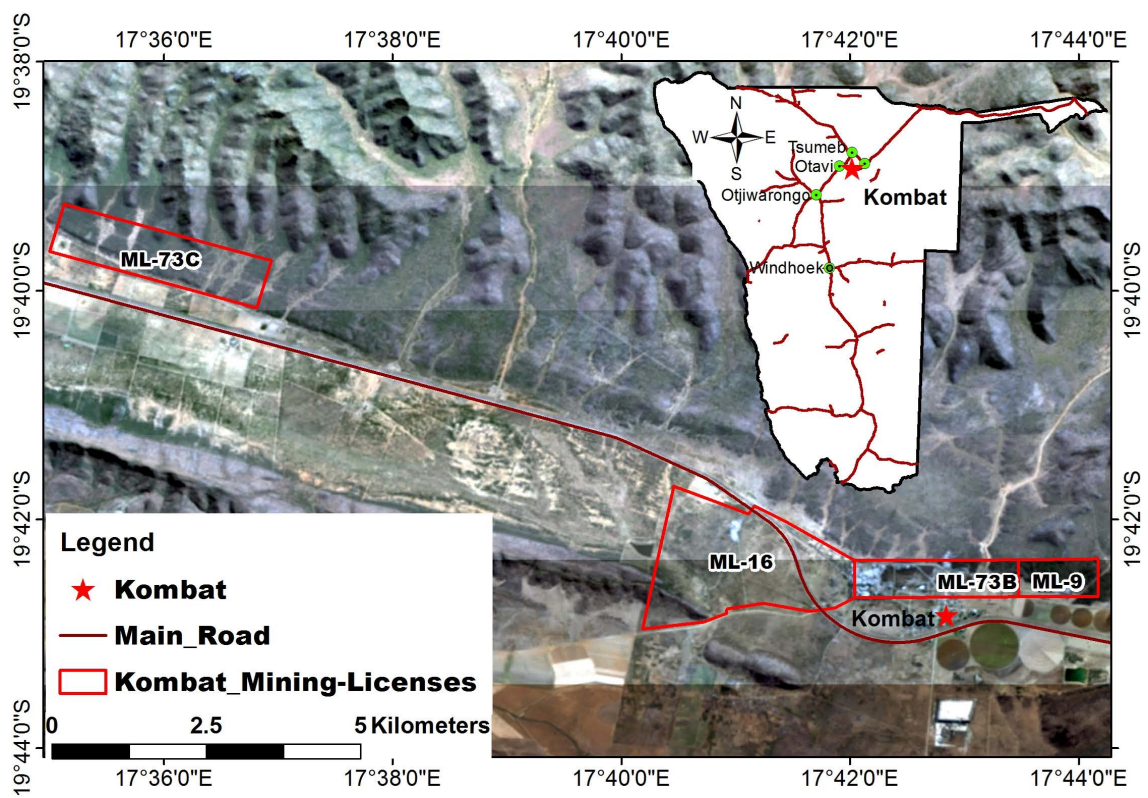

Figure 1. Location of the study area outlining Kombat Mine mining licenses (ML) on Google imagery (Image source: Google Earth pan-sharpened Landsat 8). 
conducted since the 1950s. Tsumeb Corporation Ltd (TCL) acquired the assets from OMEG and carried out soil geochemical and ground magnetic (induced polarization and seismic) surveys in the vicinity of the Kombat Mine between the 1960s to the 1990s; however, documentation and results are not available for all surveys [5]. Surface diamond drilling covering $1600 \mathrm{~m}$ of strike length from No. 1 shaft towards the Asis Far West shaft was initiated by TCL and on purchase in 1987 by Goldfields of South Africa until 1998 and transfer of ownership to Ongopolo Mining Limited. Ongopolo Mining Limited sunk an $800 \mathrm{~m}$ shaft at Asis Far West with a loan guarantee from the Namibian government in 2005. In 2006, Weatherly Mining Namibia Limited purchased the assets and drilled over 1200 holes including diamond coring (10 holes), reverse circulation (258 holes: $27,750 \mathrm{~m})$ and percussion $(16,500 \mathrm{~m})$ yielded positive results of near-surface copper mineralization over the three kilometres west of the Asis Ostore body to the No. 1 Shaft at the Kombat Minein 2007 [5].

The existing resources at the Kombat Mine are still substantial, open pit and underground indicated mineral resource estimate of 7.35 million tonnes at a grade of $0.91 \%$ copper, $0.88 \%$ lead and $0.58 \mathrm{~g} / \mathrm{t}$ silver, plus 31.76 million tonnes of inferred mineral resources at a grade of $2.21 \%$ copper, $1.33 \%$ lead and $4.42 \mathrm{~g} / \mathrm{t}$ silver [6]. The Kombat Mine is currently under care-and-maintenance status by Trigon Metals, with a plan to set up an open-pit targeting the historically overlooked low grade shallow $\mathrm{Cu}-\mathrm{Pb}(\mathrm{Ag})$ mineralization which is associated with Fe-Mn mineralization. Although different historic exploration techniques can be applied for the investigation of Kombat-style mineralization, all methods are based on the genesis of the deposit.

Historic activities at the Kombat Mine were based on the "Fracture Zone model" favoured by Tsumeb Corporation Ltd (TCL) geologists up to 1998 and Otavi Minen- und Eisenbahn Gesellschaft (OMEG) geologists from 1906 to 1941 [7]. Later a "Roof Pendants (Ore Lenses) Hanging on Rollover Structures model" [8] was mostly adopted by many authors. Hence, the genetic relationship between $\mathrm{Fe}-\mathrm{Mn}$ ore and $\mathrm{Cu}-\mathrm{Pb}(\mathrm{Ag})$ ore at the Kombat deposit remains uncertain [9].

The current study focuses on a re-evaluation of the genetic model of the Kombat polymetallic deposit, the establishment of suitable mineralogical and geochemical indicators, which can be used in exploration for additional Kombat-style polymetallic $\mathrm{Fe}-\mathrm{Mn}$ and $\mathrm{Cu}-\mathrm{Pb}(\mathrm{Ag})$ carbonate replacement deposits in the Otavi Mountainland. The study perused the development of an integrated exploration model for Kombat-style mineralization based on the association between $\mathrm{Fe}-\mathrm{Mn}$ and $\mathrm{Cu}-\mathrm{Pb}(\mathrm{Ag})$ ore at the Kombat Mine, in order to increase the mineral resource at the mine. In addition, other exploration companies might also benefit from the use of the model elsewhere in the OML or in other localities of similar geological setting.

\subsection{Methodology}

The field investigations and sampling were conducted in the open pits, particu- 
larly the Kombat Central Pit, the Iron-Manganese Pit near Shaft 03, the 900 East Pits (three pits relatively close to each other) and at the OMEG pits around the Gross Otavi Mine (Figure 2). Some rock samples were collected from the Kombat Mine underground level 2 (approximately at $40 \mathrm{~m}$ depth), the Asis Far West shaft development dumps, and from surrounding mineralized hills. In addition, underground samples from level 5 up to level 16 (approximately from $150 \mathrm{~m}$ to $600 \mathrm{~m}$ depth) were obtained from the collections of the National Earth Science Museum, Windhoek.

Sample preparation was carried out at the Geological Survey of Namibia (GSN). Samples were split. The first half was preserved, while a portion of the second half was prepared into polished blocks and thin sections to determine the nature of the ore, accessory and gangue minerals, as well as mineral paragenesis and microstructures. Other portions were crushed and milled ( $<75 \mu \mathrm{m}$ fraction) to provide homogeneous pulp for XRF whole-rock geochemical analysis to quantify the elements and for XRD analysis to provide quantitative mineralogy.

At Queens University, Kingston, Ontario, Canada, nine (9) gangue mineral samples, mainly quartz and calcite crystals selected for fluid inclusion study, were placed in a heating and freezing stage chamber (Linkham TH600 stage), which is connected to a microscope for observation of fluid bubbles (liquid). While a fraction of the material of each of the thirty-two (32) pulp samples we reanalyzed by XRD to determine the mineralogical composition of ore and host rocks at the University of Cardiff, UK.

\subsection{Location of the Study Area}

The study area is in the Grootfontein District, Otjozondjupa Region of northern

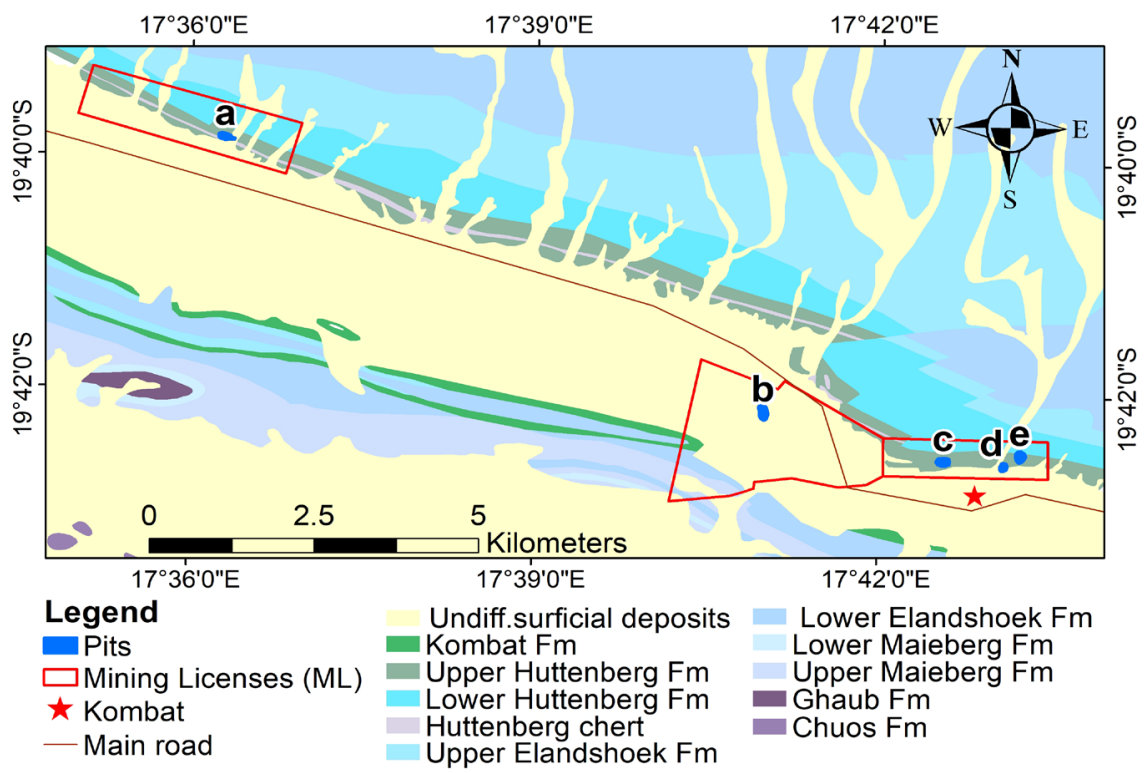

Figure 2. Sample locations at the Kombat and Gross Otavi Mine, pit areas outlined by blue polygons; (a) OMEG pits, (b) Asis Far West dumps, (c) Kombat Central pit, (d) Iron-Manganese pit, (e). 900-East pits. 
Namibia, along the B8 highway, midway between the towns of Otavi (42 km to the west) and Grootfontein (49 km to the east (Figure 1)). The area is dominated by carbonate rocks, phyllite and minor sandstone hosting the past-producing Kombat Mine ore (mining licenses: ML-9, ML-16, and ML-73B). It covers an area from the geographic (WGS84) $19^{\circ} 41^{\prime} 30^{\prime \prime S}$ to $19^{\circ} 43^{\prime} 00^{\prime \prime S}$ and $17^{\circ} 40^{\prime} 00^{\prime \prime} \mathrm{E}$ to $17^{\circ} 44^{\prime} 30^{\prime \prime E}$; Gross Otavi (ML-73C) is located between $19^{\circ} 40^{\prime} 30^{\prime \prime S}$ to $19^{\circ} 39^{\prime} 00^{\prime \prime S}$ and $17^{\circ} 35^{\prime} 00^{\prime \prime} \mathrm{E}$ to $17^{\circ} 37^{\prime} 00^{\prime \prime} \mathrm{E}$.

\section{Geology of the Kombat Mine, Otavi Mountainland (OML)}

The Kombat Mine is situated on the northern limb of the Otavi Valley Syncline [8] [10]. The basement rocks of the OML comprise felsic (alkaline/calc-alkaline granites and granodiorites) and mafic rocks (anorthosites, gabbros and amphibolites) of the Grootfontein Mafic Body (GMB) and the Grootfontein Metamorphic Complex (GMC) hereafter referred to as Grootfontein Inlier [11] [12]. A paleoproterozoic age for the Grootfontein Inlier is reasonably well constrained at $2022 \pm 15 \mathrm{Ma}$ [11] and at $1.946+299 /-333 \mathrm{Ma}$ [13] [14]. Overlying the Grootfontein Inlier are the metasedimentary rocks of the Neoproterozoic Damara Supergroup deposited during the Gondwana supercontinent aggregation from 900 to $600 \mathrm{Ma}$, involving intracratonic rifting followed by spreading, continental collision and final basin closure at $520 \mathrm{Ma}$ [15]. These rocks underwent various stages of deformation and metamorphism during the Damara Orogeny resulting in distinct tectonostratigraphic zones in Figure 3, which are based on metamorphic grade, degree and style of deformation and stratigraphy; within and around the OML these are the Northern Platform (NP), the Northern Margin Zone (NMZ) and the Northern Zone (NZ).
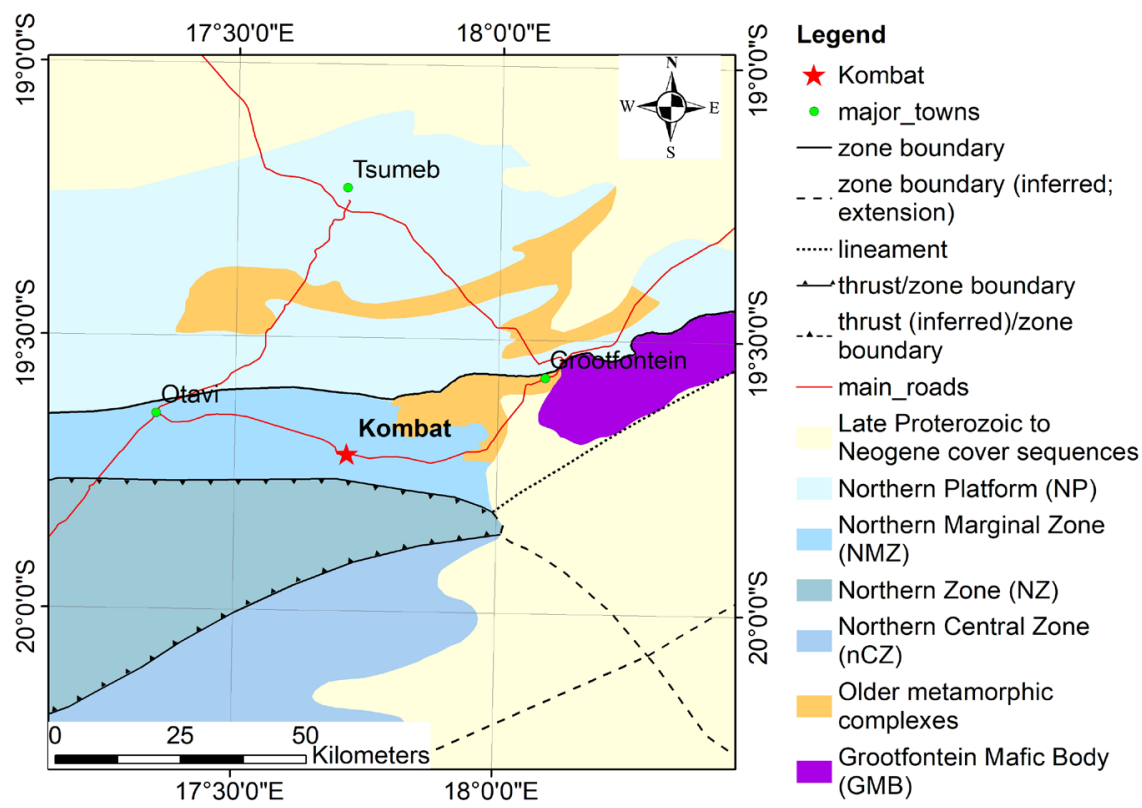

Figure 3. Tectonostratigraphic zones of the Damara Belt, showing position of Kombat Mine (red star), (source of data: Geological Survey of Namibia). 
The geological succession of the NMZ, in which the Kombat Mine-sites are situated consists of the basal Nosib Group followed by the Otavi Group carbonates and glacial deposits, and finally the Mulden Group clastic sediments. The 780 - 740 Ma Nosib Group represents horst-graben deposits [16] laid down during the break-up of the Mesoproterozoic Rodinia Supercontinent. It is made up of arkose, quartzite, shale, phyllite and local conglomerate (Nabis Formation) and the predominantly volcanogenic Askevold Formation (epidote, agglomerate, chlorite schist and dolostone). The clastic Nosib sequence is followed by the Otavi Group carbonates (Figure 2), which are subdivided into the Ombombo, Abenab and Tsumeb Subgroups by two global glaciation events, namely the 720 Ma Chuos Formation and the $635 \mathrm{Ma}$ Ghaub Formation. The two formations consist of characteristic glacial diamictites and are followed by cap carbonates represented by thick successions of carbonate platform deposits [12] [14] [17]. These carbonates were laid down during deglaciation and renewed sea level rise [10]. The syntectonic Mulden Group deposited between the first (D1) and second (D2) phases of Damaran deformation on the Northern Platform comprises the erosional debris of the developing orogen. It consists of the lower Tschudi (sandstone, shale, siltstone, conglomerate) and the upper Kombat Formation (phyllite, shale) deposited at approximately $\sim 575 \mathrm{Ma}$ [18].

\section{Geological Observations}

Field investigation and sampling was conducted in the open pits, particularly the Kombat Central Pit, the Iron-Manganese Pit near Shaft 03, the 900 East Pits (three pits relatively close to each other) and at the OMEG pits around Gross Otavi. Ore samples were collected from the Kombat Mine underground level 2, the Asis Far West shaft development dumps and from surrounding mineralized hills. The ore samples represented vein-type to breccias and disseminated mineralization, whereas those collected from underground appear to consist of massive sulfide ore minerals.

\subsection{Field Observations}

\subsubsection{Kombat Central Pit}

Kombat Central pitis approximately $100 \mathrm{~m}$ long, $50 \mathrm{~m}$ wide, and has walls with a shallow depth of about $\leq 10 \mathrm{~m}$ (Figure 4). The pit walls contain mostly veins up to $5 \mathrm{~cm}$ thick and brecciated copper ore which is dominated by chalcopyrite, bornite, chalcocite and malachite closely associated with gangue minerals including euhedral calcite crystals (Figure 4(a)), minor ferruginous chert and quartz. Also, iron-manganese minerals are hosted in the reddish-brown hematite/goethite and black manganese oxide dendrites (Figure 4(b)). These minerals are hosted in brecciated, fractured and bedded to laminated grey dolostone interbedded with laminated dark-grey ferruginous calc-silicate rocks, where bedding (S0) dips at $45^{\circ}$ to the southwest (S0: $45^{\circ} / 198^{\circ}$ ) as illustrated in Figure 4(c) and Figure 4(d). Some $15 \mathrm{~cm}$ thick lenses of mainly chalcopyrite, bornite, chalcocite and minor azurite, chrysocolla and malachite ore are found along relative 

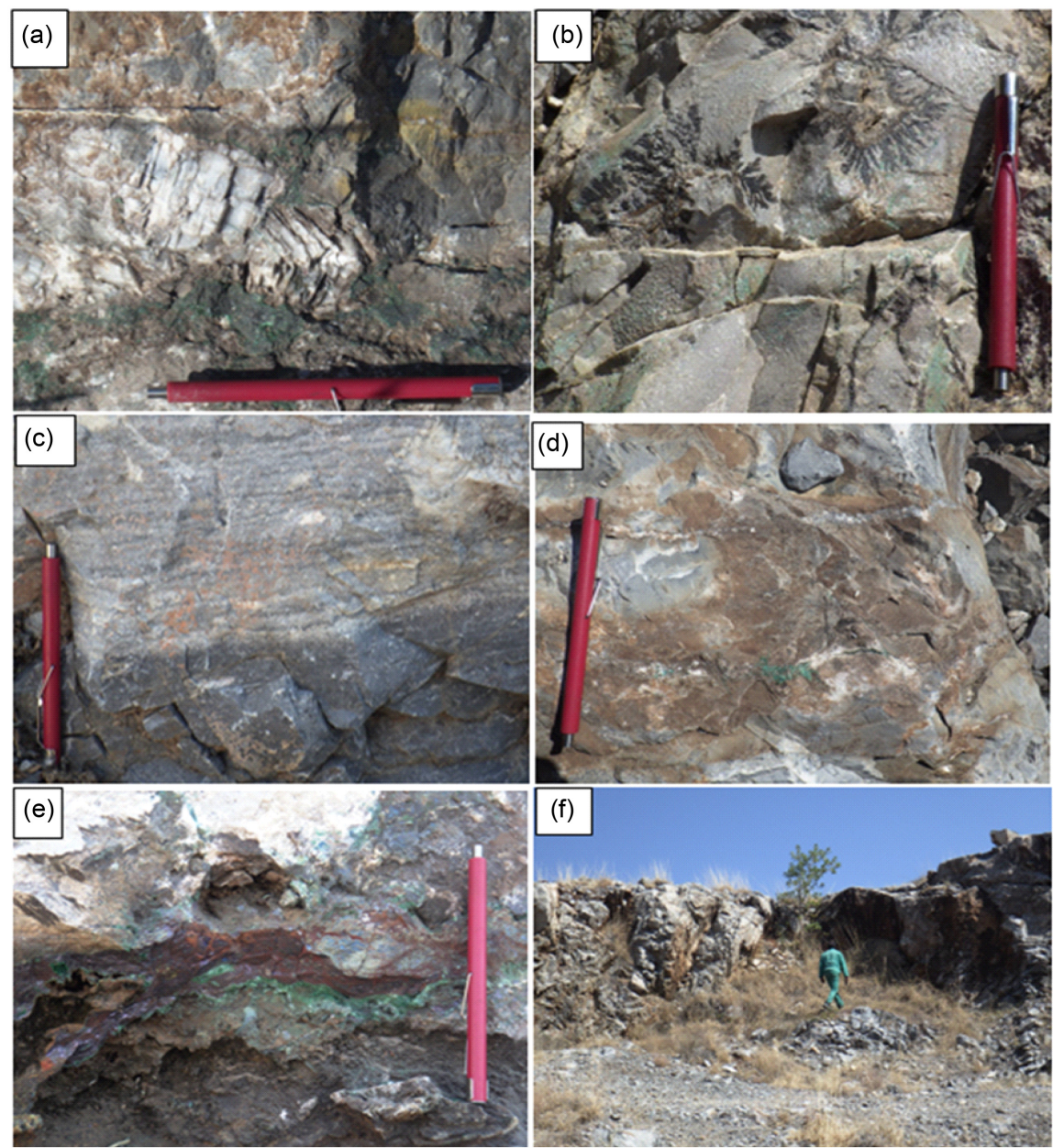

Figure 4. Central pit observations; (a) 15 by $5 \mathrm{~cm}$ long euhedral calcite surrounded by malachite and ferruginous chert; (b) dendritic manganese oxide stains on the calc-silicate rocks; (c) bedded to laminated dark-grey dolostone interbedded with calc-silicate rocks; (d) $2 \mathrm{~cm}$ wide, malachite veins closely associated with calcite and quartz gangue minerals; (e) $15 \mathrm{~cm}$ wide chalcopyrite, bornite, chalcocite and azurite lenses stained with chrysocolla and malachite along the fault plane; (f) mineralization controlling fault striking towards the west direction.

steep fault planes, where the faults dip moderately to steeply to the southwest (F: $72^{\circ} / 190^{\circ}$; Figure 4(e) and Figure 4(f). Both ore and gangue (quartz, calcite) minerals were sampled for geochemical analysis and fluid inclusions studies, respectively.

\subsubsection{Iron-Manganese (Fe-Mn) Pit}

Fe-Mn ore is exposed in the walls of a $50 \mathrm{~m}$ diameter pit shown in Figure 5, which contains up to $6 \mathrm{~m}$ wide bands of magnetite, calc-silicate layers alternating with narrow (40 cm wide) breccia zones of dolostone. The Fe-Mn rich calc-silicate layers contain a paleo-cavity/karst of one-meter diameter and $1.5 \mathrm{~m}$ height, filled with malachite, azurite and hematite, gangue minerals such as goethite, limonite, and calcite have been observed (Figures 5(a)-(a")). A patch of light-grey sandstone with pyrite dissemination (Figure 5(b), Figure 5(b')) 


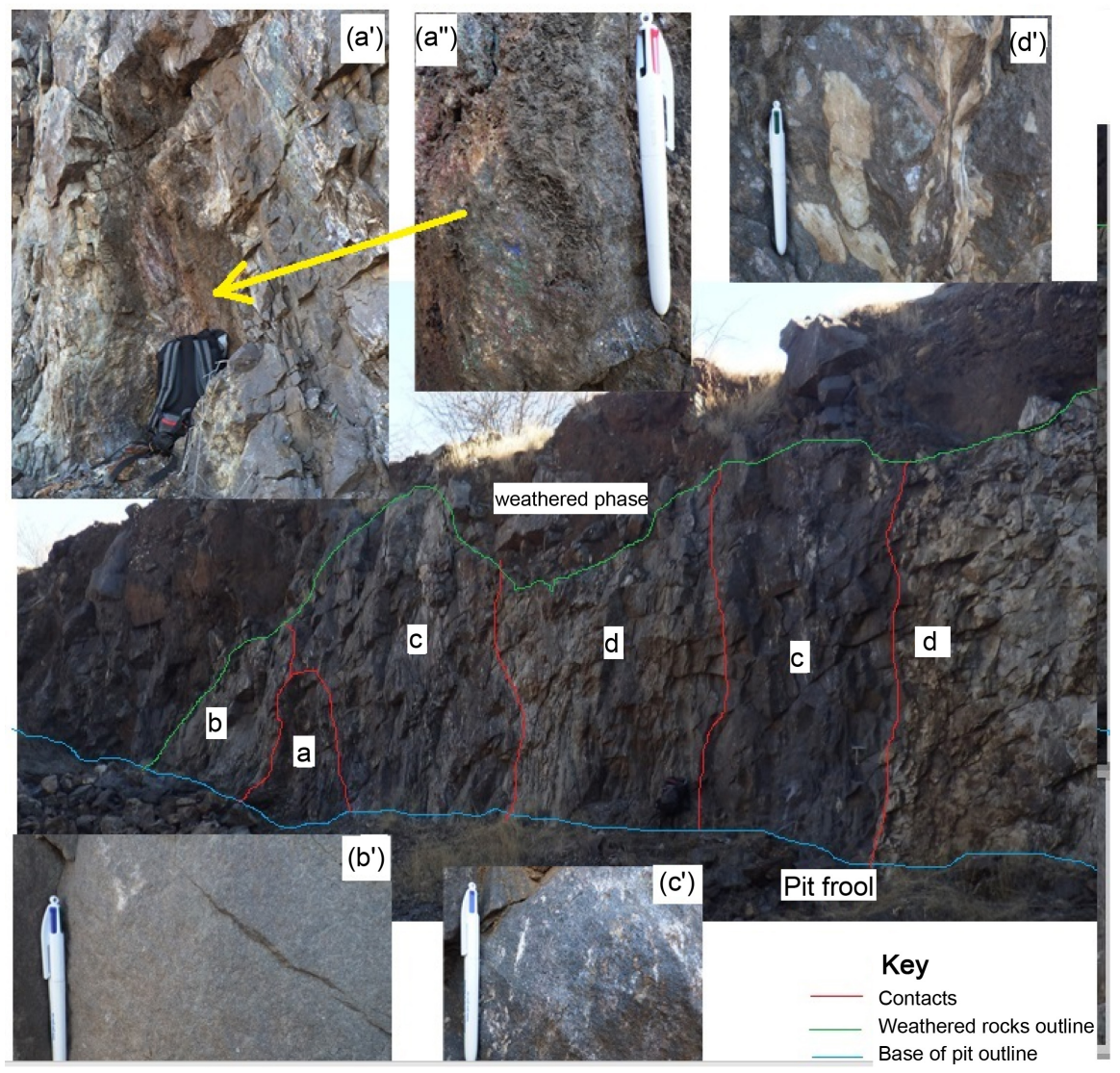

Figure 5. Fe-Mn pit observations and their zoom in sections; (a) Cavity a' with $\mathrm{Cu}$ ore minerals a", (b) Sandstone b', (c) Layered calc-silicate with magnetite c', (d) Brecciated calc-silicate d' and dolostone contact zone.

occurs next to the cavity. The sandstone appears as a boulder without depositional continuity. The calc-silicate layers host bedded Fe-Mn ore predominantly consisting of coarse, dark-grey magnetite which is strongly magnetic and reddish-brown hematite (Figure 5(c) \& Figure 5(c')); they alternate with light-brown to creamy dolostone layers containing disseminated bornite to bornite veins; chalcopyrite occurs alongside the breccia zone (Figure 5(d), Figure 5(d')). A weathered gossan outcrop similar to the aforementioned bedded Fe-Mn calc-silicate hosted ore was observed outside the pit (Figure 5(e) \& Figure $\left.5\left(e^{\prime}\right)\right)$. Most of the copper ore minerals appear localized to several shear fractures cross-cutting the light brown dolostone.

The moderate to steeply southwest-dipping shear fractures (F: $80^{\circ} / 178^{\circ}$; $76^{\circ} / 209^{\circ} ; 80^{\circ} / 180^{\circ}$ ) contain traces of chalcopyrite, bornite, galena and malachite coating. Relicts of presumably sedimentary bedding are preserved by the siliceous dolostone and calc-silicate and contain shear sense indicators such as sigma clasttails, ladder veins or tension gashes of a reverse fault system (Figure 6).

\subsubsection{Asis Far West Shaft Development Dumps and Hill Outcrop}

The Asis Far West Shaft development dumps and hill outcrop contain vein- to disseminated-type copper mineralization, mostly consisting of chalcopyrite and 

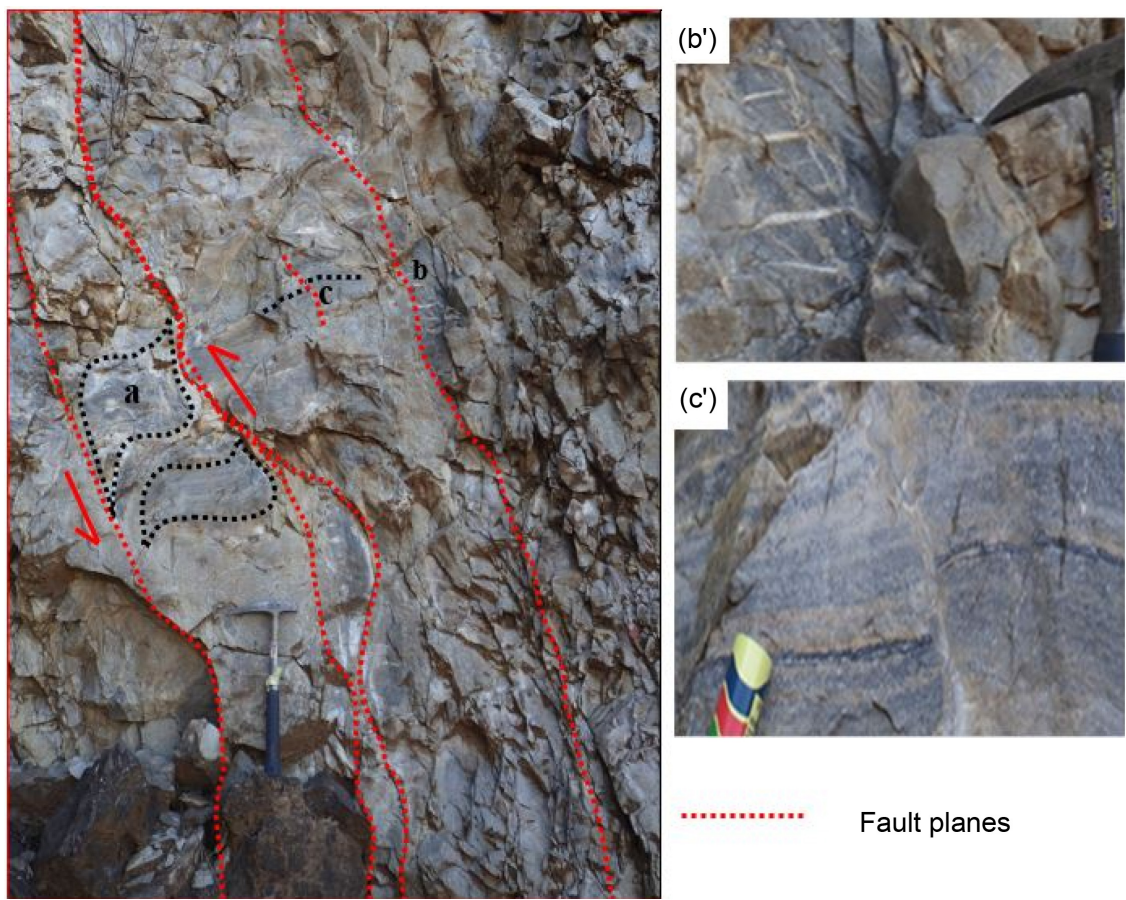

Figure 6. Sense of shear and evidence of displacement for a reverse fault system: (a) sigma clast-tails; (b) ladder veins/tension gashes, close-up in (c) fault offset in the calc-silicate layers, close-up in c (looking towards the east).

bornite with minor chalcocite and surface malachite stains. Figure 7 (a) shows the dumped materials from which two random grab samples were collected. Figure 7 (b) shows a brecciated dolostone hill located at $1.2 \mathrm{~km}$ distance southwest from the shaft, containing chalcocite and malachite mineralization in karst fractures; the mineralization is associated with reddish ferruginous chert as well as recrystallized euhedral white calcite crystals.

\subsubsection{0-East Pits}

The three open pits are located within $50 \mathrm{~m}$ of each other, ranging from 20 to 50 $\mathrm{m}$ in diameter. Figure 8 illustrates pit walls consist of well-exposed remnants of laminated, folded calc-silicate layers that host malachite as fracture plane coatings and veinlets. A massive-fractured grey dolostone contains both veins and disseminations of chalcopyrite, bornite, chalcocite and galena (Figure 8(a), Figure 8(b) ore minerals. Occasionally, patches of white calcite crystals are closely associated with quartz and disseminations of galena, pyrite and chalcopyrite. Also, the ore minerals form rims around the white calcite crystals shown in Figure $8(\mathrm{c})$, Figure $8(\mathrm{~d})$ ). Fault and cavities structures are exposed in the walls of the pits. The cavities contain matrix-supported ferruginous dolostone breccia associated with recrystallized calcite up to $25 \mathrm{~cm}$ wide dark-grey (smoky) crystals and malachite stains (Figure 8(e)). In some places, the cavities appear connected by very steep fracture planes (F: $90^{\circ} / 205^{\circ}$ ) of a fault system (Figure 8(f)), which could be explained by the presence of unmineralized calcite tension gashes (ladder veins) shown in Figure $8(\mathrm{~g})$ ). 

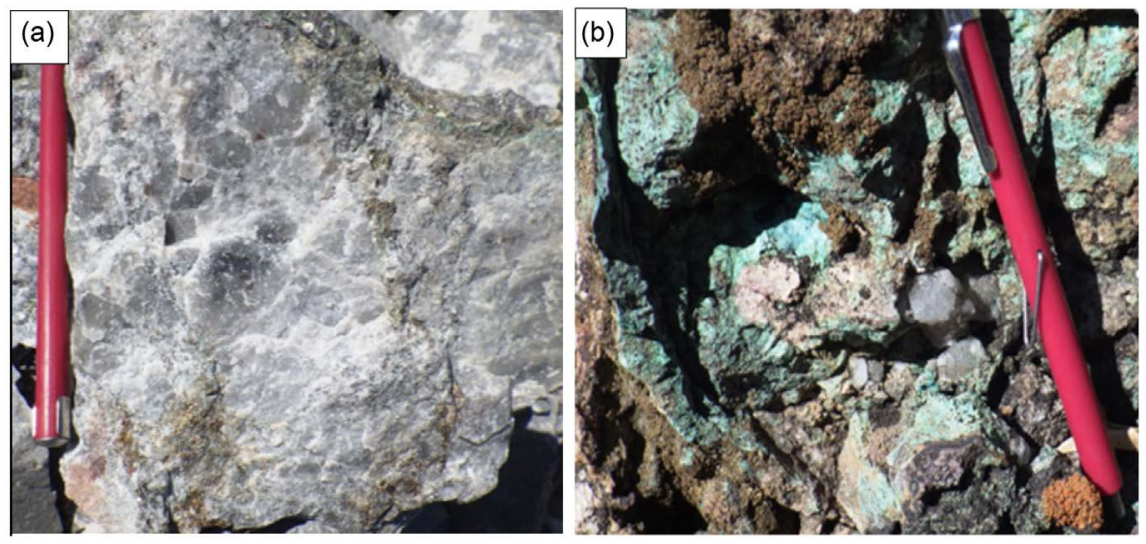

Figure 7. Asis Far West observations; (a) veins of chalcopyrite and bornite from the shaft development dumps; (b) chalcopyrite and malachite mineralization in karst fractures associated with ferruginous chert and euhedral white calcite crystals.
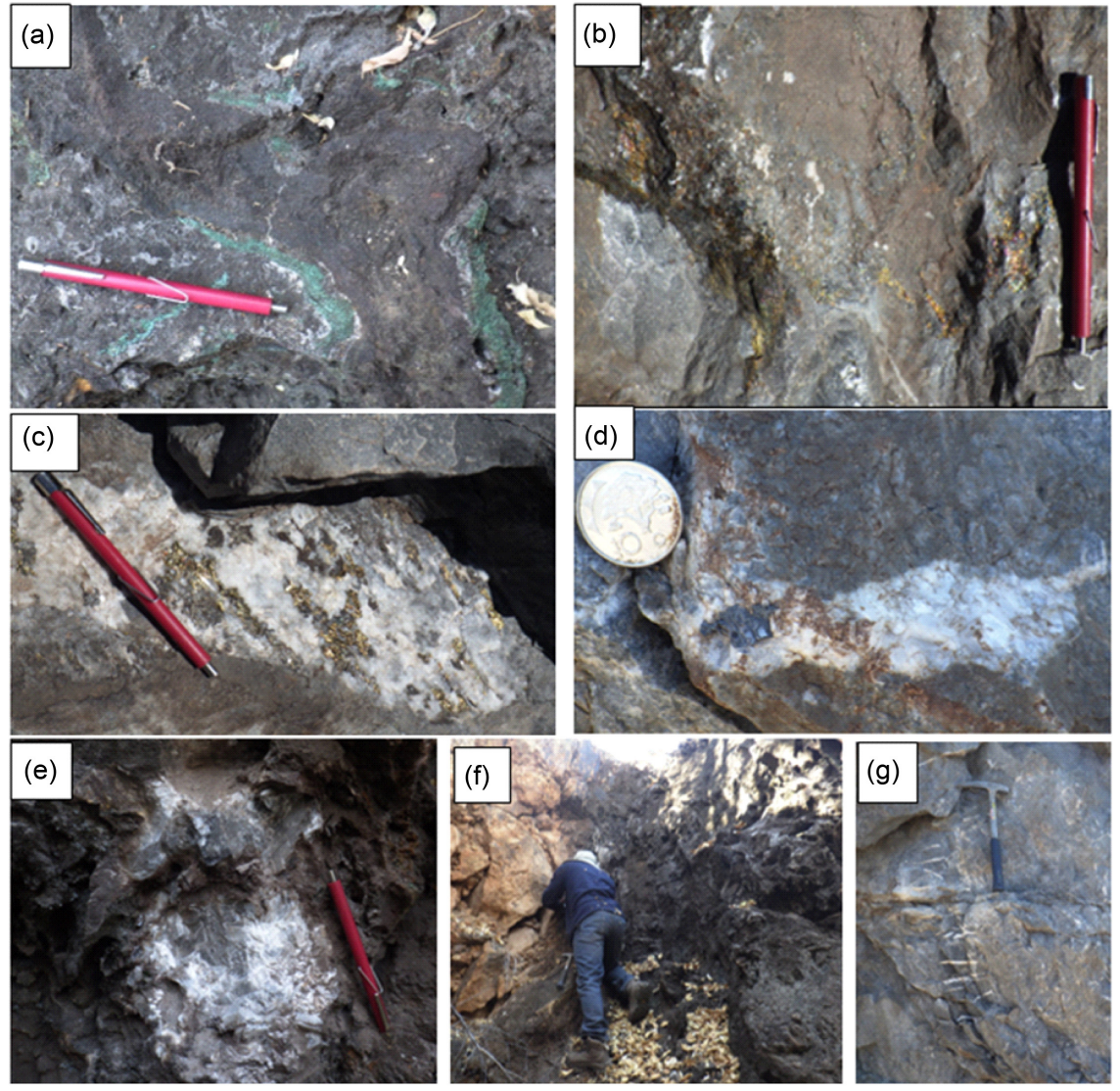

Figure 8. 900-East pit observations; (a) folded malachite veins in calc-silicate; (b) grey dolostone with chalcopyrite, bornite, chalcocite and galena veins; (c) calcite crystals closely associated with quartz, galena and chalcopyrite fracture fillings; (d) calcite with galena crystals; (e) smoky calcite crystals in ferruginous breccia; (f) fractured fault plane (looking towards the east direction); (g) calcite tension gashes.

\subsubsection{OMEG Pits}

Several historically mined narrow pits of about $4 \mathrm{~m}$ width and up to $30 \mathrm{~m}$ length illustrated in Figure 9(a) are cutting through the laminated (S0: $41^{\circ} / 226^{\circ}$ ), 

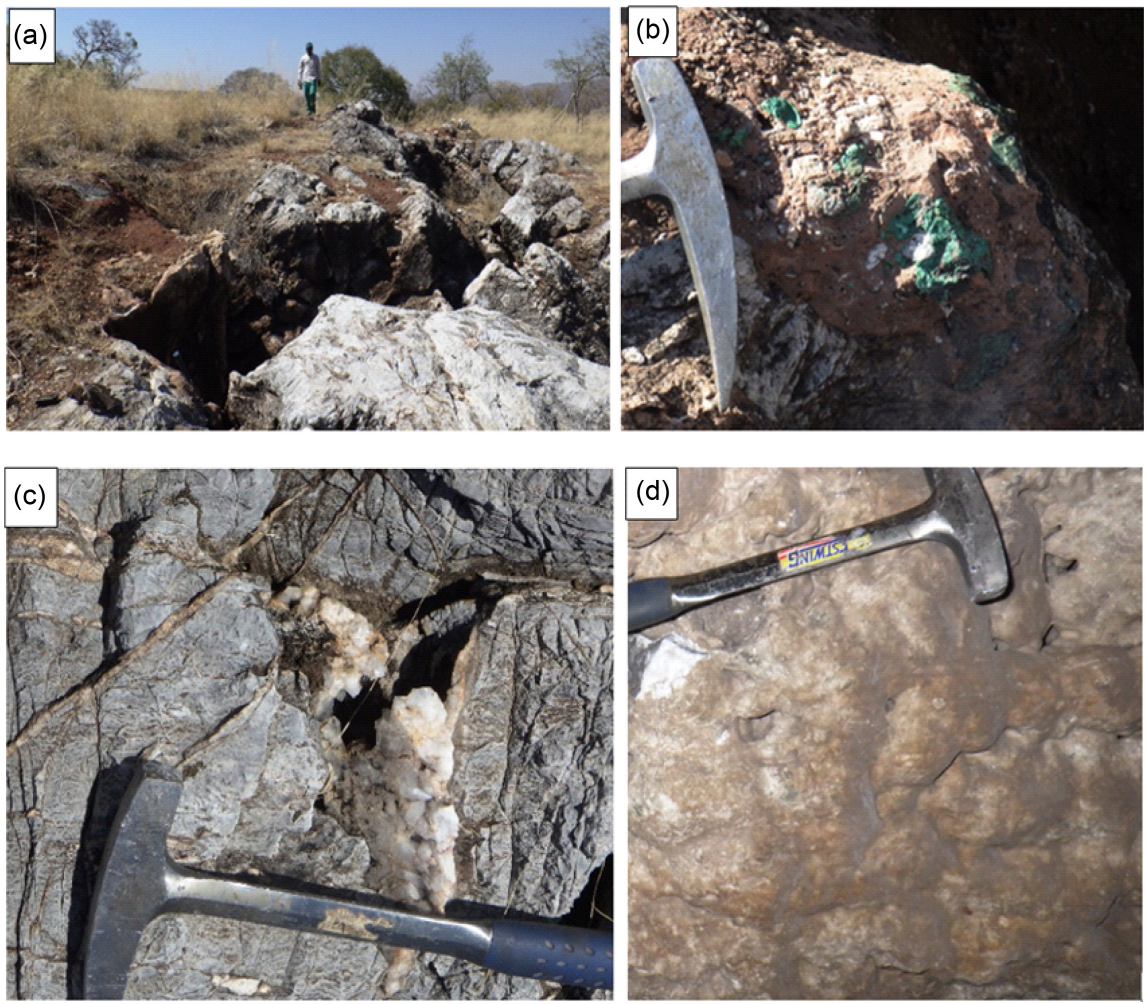

Figure 9. OMEG Gross Otavi pits observations; (a) historically mined narrow pits (looking towards the west direction); (b) matrix-supported breccia deposit of chalcocite, malachite and hematite ore; (c) euhedral to subhedral quartz crystals within the quartz veins; (d) botryoidal-shaped unit of brownish calc-silicate in the Gross Otavi adit.

fractured to brecciated grey dolostone with ferruginous chert of the upper Hüttenberg Fm [17]. The dolostone contains the paleo-cavities that appear interconnected by steep fault planes (F: $90^{\circ} / 205^{\circ} ; 65^{\circ} / 178^{\circ}$ ). These cavities are characterized by a reddish-brown ferruginous and matrix-supported breccia containing chalcocite, malachite and hematite ore associated with quartz and calcite gangue minerals (Figure 9(b)). Also, some black manganese dendritic structures as well as euhedral to subhedral quartz veins have been observed (Figure 9(c)) and sampled for fluid inclusion analysis. One kilometer further to the west, an adit cut into a hill of laminated, grey, ferruginous and cherty dolostone hosting chalcocite and malachite mineralization along the ramp roof proved unsafe for sampling. However, a well-exposed botryoidal shaped unit of brownish calc-silicate and whitish siliceous surfaces along the ramp wall (Figure 9(d)) was sampled.

\subsection{Structural Interpretation}

Figure 10 shows the stereonet plots of structural measurements such as preserved primary structure relicts of bedding or lamination planes (S0) associated with $\mathrm{Fe}-\mathrm{Mn}$ ore, as well as secondary structures including $\mathrm{Cu}-\mathrm{Pb}$ mineralized faults and shear fractures (F). The faults and shear fractures associated with 


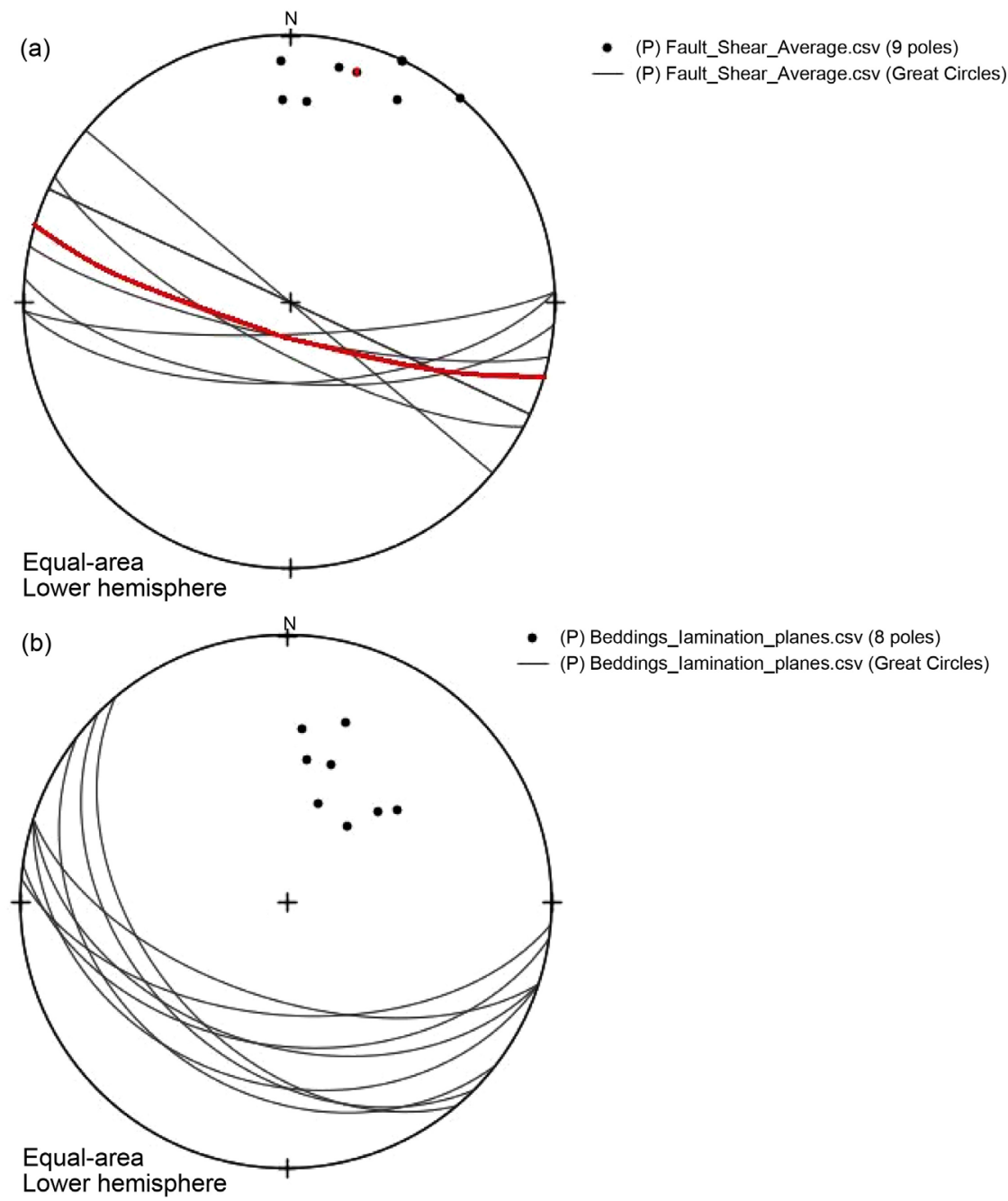

Figure 10. Structural analysis of field measurements: (a) Faults, Shear fractures with an average plane in red (F); (b) Sedimentary beddings and laminations (So).

$\mathrm{Cu}-\mathrm{Pb}$ ore turned out to be steeper dipping (Figure 10(a)) with an average fracture plane of $\mathrm{F}: 79^{\circ} / 195^{\circ}$, while bedding and lamination planes (S0: $44^{\circ} / 205^{\circ}$ ) are relatively shallow dipping (Figure 10(b)).

\subsection{Mineralogy and Petrology of the Ores}

The polished block samples were viewed under 20-micron magnification of a reflected light microscope to determine their contents of ore minerals and to obtain photomicrographs of these ores. The image in Figure 11 shows that brown bornite $(\mathrm{Bn})$ is the dominant ore mineral, followed by yellow to orange chalcopyrite $(\mathrm{Cp})$. Both bornite and chalcopyrite are being replaced by light-brown twin lamellae of chalcocite $(\mathrm{Cc})$. The bluish covellite $(\mathrm{Cv})$ exsolution lamellae emerge out of chalcocite and bornite, while some covellite veins cross-cut bornite, chalcopyrite and chalcocite are terminated by faint-yellowish or creamy pyrite (Py). Hence, the copper ore minerals observed could have originated in the following paragenetic sequence: Bornite $(\mathrm{Bn}) \rightarrow$ Chalcopyrite $(\mathrm{Cp}) \rightarrow$ Chalcocite 

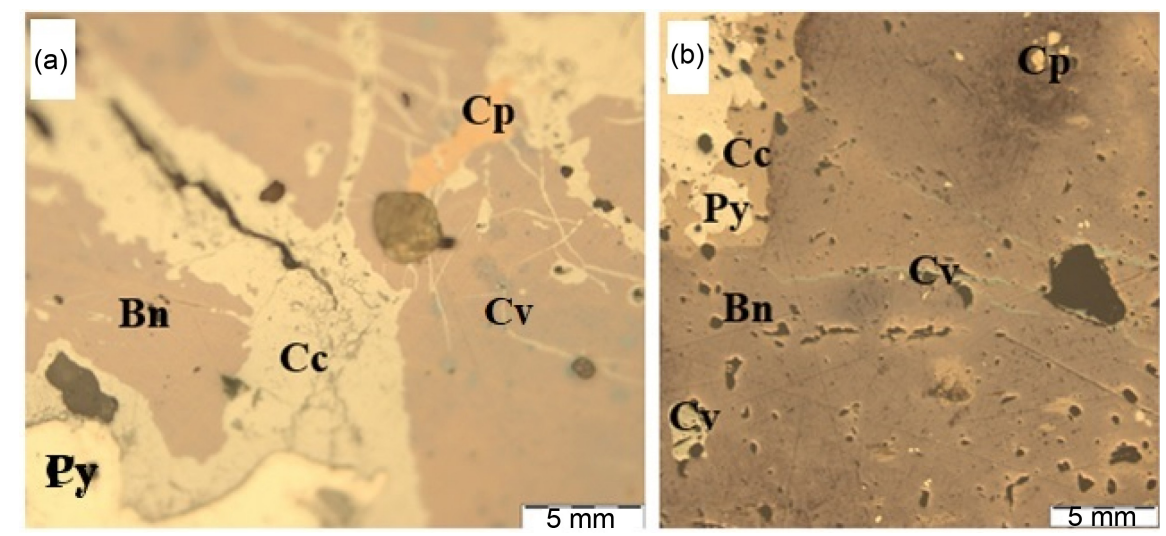

Figure 11. Ore minerals in samples from the National Earth Science Museum; (a) Sample 8680: Massive brown bornite $(\mathrm{Bn})$, with exsolved dull bluish covellite $(\mathrm{Cv})$ and orange chalcopyrite $(\mathrm{Cp})$; replacement of bornite is cross-cut by a vein filled with light-brown chalcocite (Cc) and light-yellow pyrite (Py). (b) Sample 8650: Brown bornite (Bn), replaced by chalcopyrite $(\mathrm{Cp})$ and chalcocite $(\mathrm{Cc})$, while covellite veins $(\mathrm{Cv})$ cross-cutting both bornite and chalcocite are terminated by pyrite (Py).

$(\mathrm{Cc}) \rightarrow$ Covellite $(\mathrm{Cv}) \rightarrow$ Pyrite (Py). Figure 12 reveals foliated iron and manganese ore minerals comprising hausmannite $(\mathrm{Hs})$ and coexisting magnetite $(\mathrm{Mt})$ and pyrite (Py); hematite $(\mathrm{Hm})$ and jacobsite $(\mathrm{Jb})$ appear as exsolution lamellae within the syn-sedimentary chalcopyrite generation, which is associated with bioturbation (Figure 12(c)). Hence, the overall paragenetic sequence of the Kombat deposit in Figure 13 can be summarized as follows: Syn-sedimentary (iron-manganese + copper) $\rightarrow$ Hydrothermal (primary copper ore minerals) $\rightarrow$ Secondary copper ore minerals $\rightarrow$ Alteration of secondary ore minerals (supergene enrichment).

Thin-section images in Figure 14 show associated minerals such as possible euhedral calcite crystals with lamellae twins, which are completely bounded by distinct crystal faces representing unhindered growth such as crystallization in a hydrothermal fluid, cavity or fault opening (Sample AN19206; Figure 14(i)). Furthermore, pseudomorphs of amphibole and replacement textures (Sample AN19217; Figure 14(j)) could be related to decompression, particularly to episodes of rapid exhumation during deformation due to the Damara collision event. Replacement textures include intergrowths of ore minerals forming at the expense of previously stable amphiboles. Sample AN19211 shows strongly deformed crystal textures such as kinking or bent twin lamellae in calcite/dolomite and partially recrystallized fine-grained polygonal aggregate or cross-cutting subgrain patterns with dendritic inclusion textures of exsolved manganese (Figure 14(j), Figure 14(k)) which may represent the brittle-ductile transition textures of deformation. Granoblastic textures of subhedral and anhedral dolomite, quartz with undulatory extinction, amphiboles with secondary intergrowths of opaque, presumably ore minerals (Samples AN19200 and AN19203; Figure 14(1), Figure $14(\mathrm{~m})$ ) could be due to thermally induced annealing, which created polycrystalline grain aggregates and dissolution textures [19]. In addition, 

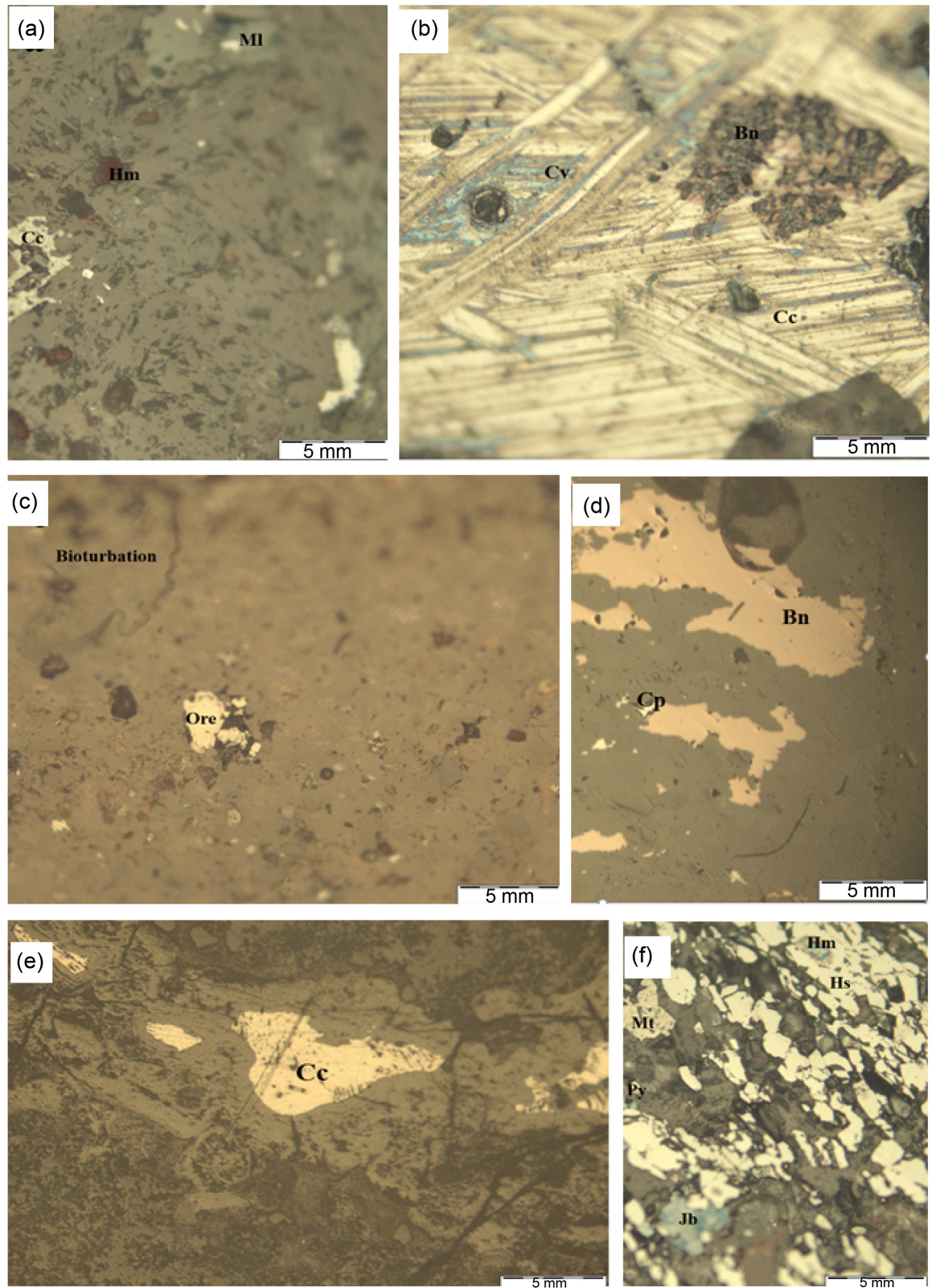

Figure 12. Field sample ore minerals; (a) Sample AN19206: Chalcocite (Cc) sur-rounded by malachite $(\mathrm{Ml})$ and hematite disseminations (Hm); (b) Sample AN19214: Massive chalcocite $(\mathrm{Cc})$ lamellae replacing bornite $(\mathrm{Bn})$ while covellite $(\mathrm{Cv})$ is re-placing both bornite and Chalcocite. (c) Sample AN19221: Bioturbation (animal bar-row) next to the yellow ore mineral. (d) Sample AN19211: Brown bornite (Bn) being replaced by yellow chalcopyrite (Cp). (e) Sample AN AN19228: Micro-boudinaged of chalcocite (Cc). (f) Sample AN19193: Foliated hausmannite (Hs), magnetite (Mt) pyrite (Py) and hematite $(\mathrm{Hm})$ disseminations with traces of Jacobsite $(\mathrm{Jb})$.

strongly deformed and kinked crystals of dolomite (Sample AN19223), and albiteporphyroblasts with sigmoidal inclusion trails defined by tiny calcite and fine-grained muscovite and sericite (Sample AN19223; Figure 14(n), Figure 14(o)) provide strong evidence of rock movements in agreement with the "Fracture Zone Model" [7]. 


\begin{tabular}{|l|l|l|l|l|l|}
\hline $\begin{array}{l}\text { Ore } \\
\text { minerals }\end{array}$ & $\begin{array}{l}\text { Syn- } \\
\text { Sedimentar }\end{array}$ & $\begin{array}{l}\text { Hydrotherm } \\
\text { al }\end{array}$ & Secondary & $\begin{array}{l}\text { 1st } \\
\text { Alteration }\end{array}$ & $\begin{array}{l}\text { 2nd } \\
\text { Alteration }\end{array}$ \\
\hline Appearance & banded (S0) & (fractures) & (S3) & (Enrichment) & (Oxides) \\
\hline Hausimmanite & & & & & \\
\hline Magnetite & & & & & \\
\hline jacobsite & & & & & \\
\hline Chalcopyrite & & & & & \\
\hline Galena & & & & & \\
\hline Bornite & & & & & \\
\hline Chalcocite & & & & & \\
\hline Covellite & & & & & \\
\hline Pyrite & & & & & \\
\hline Hematite & & & & & \\
\hline Malachite & & & & & \\
\hline
\end{tabular}

Figure 13. Syn-sedimentary hausimmanite (black), magnetite (grey), jacobsite (light-grey), chalcocite (orange); Hydrothermal chalcopyrite (orange), galena (light brown), Bornite (brown) due todue to major fracture system development. Secondary Bornite (brown), chalcocite (pale-yellow), covellite (blue) due to reactivation of fractures. First alteration chalcocite (pale-yellow), covelite (blue,) enrichment breccia, cavity, fault/fracture fillings. Secondary alterations malachite (green) oxides. Pyrite (yellow) and hematites (red) appears throughout the timing of Kombat ore forming system.

\section{Analytical Methods}

The samples collected from the study area were analyzed by X-ray fluorescence (XRF), X-ray diffraction (XRD), and heating and freezing (Linkham TH600) stage.

\subsection{X-Ray Fluorescence (Portable XRF)}

A total of forty (40) pulp samples ( $<75 \mu \mathrm{m}$ fraction) including four quality control/quality assurance (QC/QA) standards of $0.5 \% \mathrm{Cu}, 5 \% \mathrm{Fe} ; 2 \% \mathrm{Cu}, 5 \% \mathrm{Fe} ; 5 \%$ $\mathrm{Cu}, 5 \% \mathrm{Fe}$; and $20 \% \mathrm{Cu}, 5 \% \mathrm{Fe}$, four blanks samples prepared from quartz chips and four duplicates of AN19199, AN19209, AN19219 and 8659 randomly selected from within a group of ten samples arranged according to the increasing order of sample numbers. The QC/QA plots have proven minimal or no contamination with the coefficient values $\mathrm{R}^{2} \geq 0.99$ for copper and iron. Each sample was subjected to portable XRF whole-rock analysis in order to determine major and trace elements. The process involved filling up a sample holder, covered with a thin plastics film at the top and a sample label at the bottom. Each pulp sample was placed in the measuring compartment for 120 seconds at mining mode (\%) with a portable XRF instrument at the GSN's geochemistry laboratory.

\subsection{X-Ray Diffraction (XRD)}

X-Ray Diffraction (XRD) was carried out on thirty-two (32) samples prepared by crushing and milling $(<75 \mu \mathrm{m}$ fraction) to provide homogeneous pulp for 

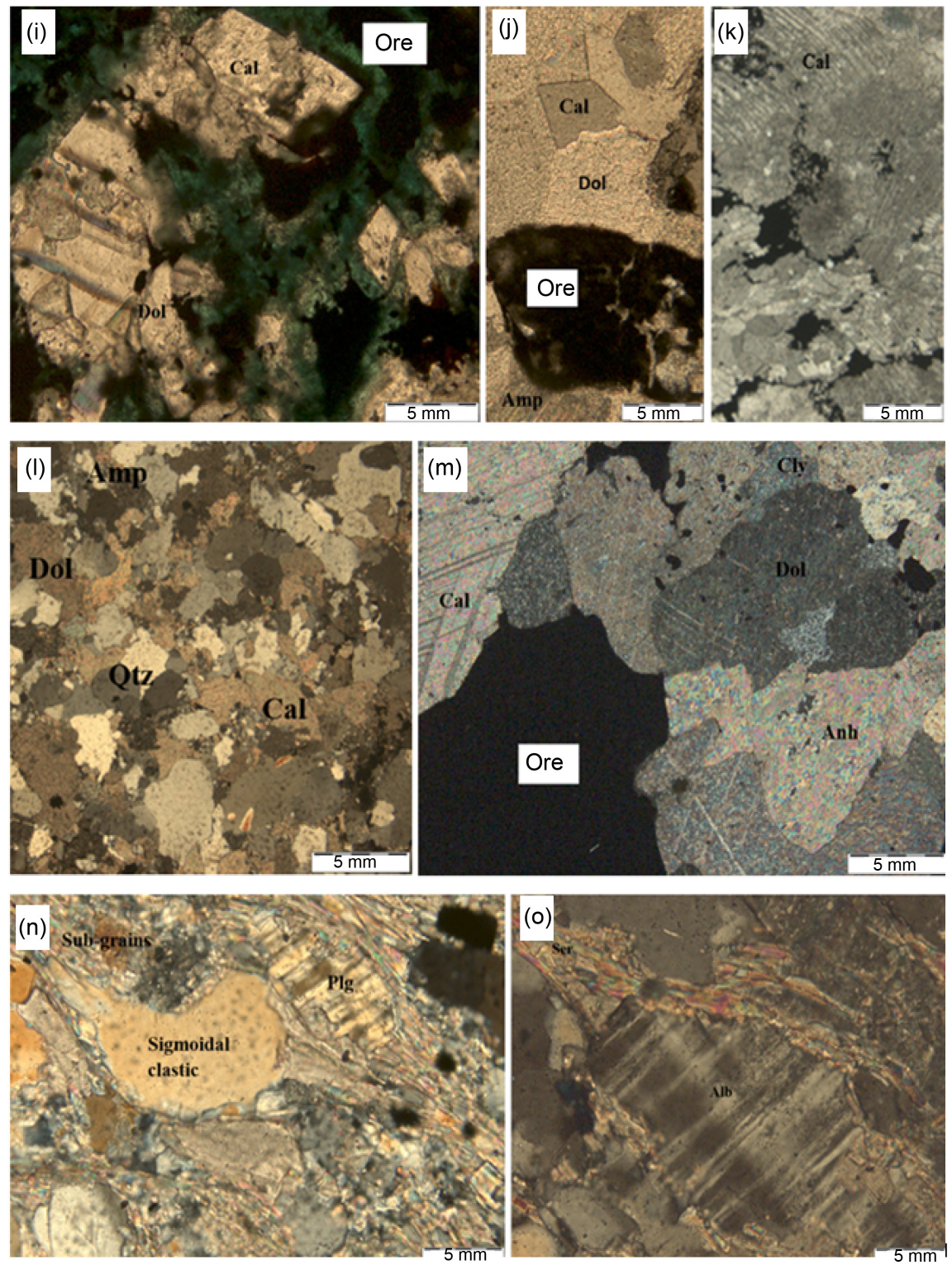

Figure 14. These are photomicrographs showing gangue minerals in samples; (i) Sam-ple AN19206: Euhedral calcite crystals with lamellae twins. (j) Sample AN19217: Pseudomorphic replacement of plagioclase and amphiboles by the ore minerals. (k) Sample AN19211: Strongly deformed crystals with bent twin lamellae of calcite, subgrain patterns and dendritic textures inclusion; (l) Sample AN19200: Granoblastic textures of subhedral and anhedral dolomite, quartz with undulatory extinction, am-phiboles with secondary intergrowths of opaque minerals. (m) Sample AN19203: Granoblastic textures of calcite (Cal) with polysynthetic glide twins, dolomite (Dol) with deformation lamellae twins. (n) Sample AN19223: Strongly deformed and kinked crystals of dolomite porphyroblasts with sigmoidal inclusion trails defined by tiny calcite. (o) Sample AN19223: Sericitization, consumption of the albite (Alb) component produces fine-grained sericite (Ser).

analysis to determine mineralogical composition of ore and host rocks. Bulk mineralogy was completed on powdered samples and mineral identification under-taken in PC IDENTIFY software. Analysis utilized the Panalytical X Pertdiffractometer. 


\subsection{Heating and Freezing (Linkham TH600) Stage}

A total of nine (9) gangue mineral samples, mainly quartz and calcite crystals, were selected for fluid inclusion studies. Each sample was placed in the heating and freezing stage chamber (Linkham TH600 stage) which was connected to the microscope for observation of fluid bubbles (liquid) inside the mineral. The stage was set at a fixed heating rate of $90^{\circ} \mathrm{C}$ per minute, then reduced to $1^{\circ} \mathrm{C}$ per minute close to the point when the bubble (liquid) and the rock (solid) phases start to homogenize into a solution. This temperature was recorded as the homogenization temperature, representing the minimum temperature of formation. The stage cooled until frozen with nitrogen (N2) gas. Once the solution freezes, the temperature is taken and related to $\mathrm{NaCl} \%$ solution based on the Shepherd 1981 method [20].

\section{Results and Interpretation}

\subsection{XRD Major, Minor and Trace Minerals of Kombat Mine Samples}

The X-Ray Diffraction (XRD) results presented in Table 1, shows that out of the fifty-nine (59) minerals identified in the Kombat samples, chalcopyrite, bornite, covellite and galena, with minor chalcocite, and sphalerite are the most common ones in the $\mathrm{Cu}-\mathrm{Pb}(\mathrm{Ag}-\mathrm{Zn}-\mathrm{V})$ ore whiles, the Fe-Mn ore is dominated by hausmannite and hematite, with minor pyrite, jacobsite, manganite, magnetite, pyrolusite, rhodonite, and pyrobelonite. Associated gangue minerals are chiefly dolomite, quartz, calcite, ankerite, illite, and defrenite, with minor albite, biotite, chlorite, kaolinite, muscovite, epidote, anhydrite, gypsum, langite, and allegrite; the remainder of the minerals occurs in trace quantities.

\subsection{Trace Elements of Kombat Mine Samples}

XRF results are plotted on the discriminant ternary diagram for sedimentary rocks in Figure 15, which shows that the Kombat samplesfall within the hydrothermal, diagenetic and mixed (hydrothermal-diagenetic-hydrogenetic) fields. On sample localities based ternary diagrams in Figure 16, samples from Central Pit, Asis Far West and the 900 East Pits are seen to fall mostly into the hydrothermal field. Dual fields of hydrothermal-diagenetic origin were observed for the samples from the National Earth Science Museum, while some samples from the Fe-Mn Pit and the OMEG pits indicated mixed fields of hydrothermal-hydrogenetic-diagenetic. Plots of $\mathrm{Pb}-\mathrm{Cu}-\mathrm{Zn}$ fields in Figure 17 (a) compared to Figure 17(b) of VMS/SEDEX [21] [22] [23] show that most of the Kombat Mine samples plotted in the $\mathrm{Cu}-\mathrm{Pb}$ SEDEX field and are clearly distinct from VMS deposits as illustrated on individual sample localities in Figure 18 [24]. In addition, various elements were plotted against copper on the binary diagrams in Figure 19 \& Figure 20 to display the Pearson correlation coefficient, a measure of the strength of a linear association between a selected element and copper denoted by $r$ [25]. Figure 19 shows a negative Pearson correlation 
Table 1. XRD major $\left(^{* * *}\right)$, minor $\left({ }^{* *}\right)$ and trace $\left({ }^{*}\right)$ minerals of Kombat Mine samples.

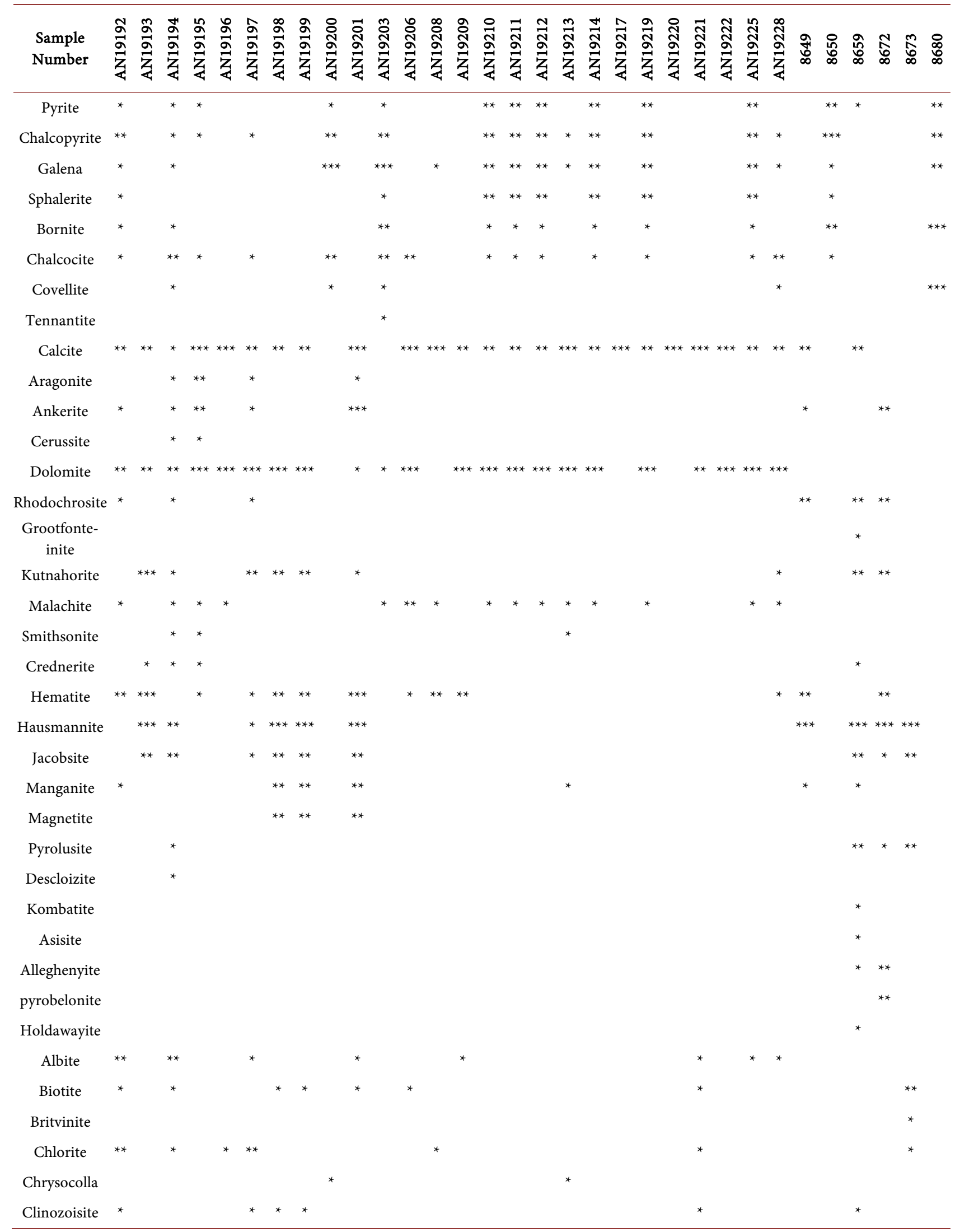




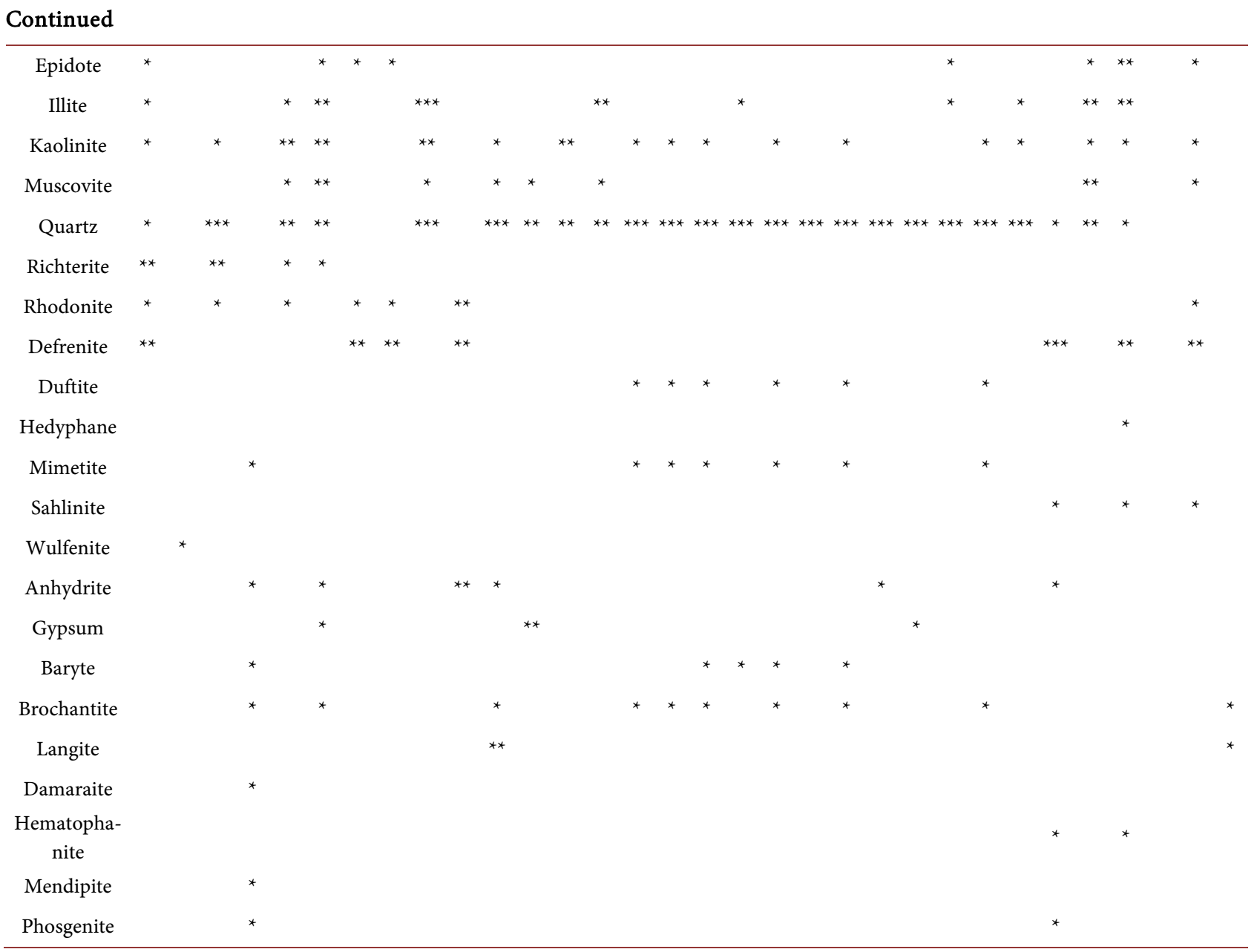

coefficient for $\mathrm{Ca}, \mathrm{Ba}, \mathrm{Mg}, \mathrm{P}, \mathrm{Sr}, \mathrm{Sb}, \mathrm{Ti}$ and $\mathrm{Mn}$, while Figure 20 displays elements with a positive Pearson correlation coefficient (Ag, S, Zn, Mo, Pb, Fe, As and $\mathrm{W}$ ). Thus, elements with moderate to strong linear association $r \geq 0.4$ [25] with copper were selected for coefficient of determination $\left(R^{2}\right)$ evaluation and the results in Figure 21 shows that $\mathrm{W}, \mathrm{S}, \mathrm{Mo}, \mathrm{Ag}, \mathrm{Pb}, \mathrm{Ca}$ and $\mathrm{Mn}$ have a significant correlation of $\mathrm{R}^{2} \approx 0.70$ with $\mathrm{Cu}$.

\subsection{Fluid Inclusion Analysis of Kombat Mine Samples}

Results were obtained from an average of five primary or second-generation of fluid inclusions per sample of calcite, quartz, sphalerite, wulfenite and cerussite. Table 2 shows a wide range of mean temperatures for primary inclusions ranging from $64^{\circ} \mathrm{C}$ to $302^{\circ} \mathrm{C}$, while that of secondary inclusions is slightly lower ranging from $58^{\circ} \mathrm{C}$ to $167^{\circ} \mathrm{C}$. In contrast, mean freezing temperatures range from $-26.4^{\circ} \mathrm{C}$ to $-1.8^{\circ} \mathrm{C}$, which gave salinity records from 2.1 to $26.4 \mathrm{wt} \% \mathrm{NaCl}$ equivalent. Corrected mean homogenization temperatures based on diagrams for correcting fluid inclusion homogenization temperatures for compositions ranging from 0 to 25 percent $\mathrm{NaCl}$ up to $400^{\circ} \mathrm{C}$ and $200 \mathrm{MPa}$ [8] [28] in Figure 22 shows that total homogenization occurred at temperatures ranging from $160^{\circ} \mathrm{C}$ to $200^{\circ} \mathrm{C}$. 
Table 2. Heating and freezing (Linkham TH600) stage fluid inclusion analysis results for Kombat Mine samples.

\begin{tabular}{|c|c|c|c|c|c|c|c|c|c|}
\hline Sample & Host & $\begin{array}{c}\text { Type of } \\
\text { generation }\end{array}$ & $\begin{array}{l}\text { Number } \\
\text { inclusions } \\
\text { analysed }\end{array}$ & $\begin{array}{c}\text { Mean } \\
\text { Freezing } \\
\text { temp, }{ }^{\circ} \mathrm{C}\end{array}$ & $\begin{array}{l}\text { Standard } \\
\text { Deviation }\end{array}$ & $\begin{array}{l}\text { Eqiu } \\
\mathrm{NaCl} \\
\text { wt \% }\end{array}$ & $\begin{array}{c}\text { Mean } \\
\text { Homogenization } \\
\text { Temp, }{ }^{\circ} \mathrm{C}\end{array}$ & $\begin{array}{l}\text { Standard } \\
\text { Deviation }\end{array}$ & $\begin{array}{c}\text { Corrected Mean } \\
\text { Homogenization } \\
\text { Temp, }{ }^{\circ} \mathrm{C}\end{array}$ \\
\hline \multirow[t]{2}{*}{ AN19208 } & Calcite & secondary & 5.00 & -3.50 & 1.3 & 5.00 & 120.00 & 64.0 & 160.00 \\
\hline & Calcite & primary & 6.00 & -6.50 & 2.1 & 8.00 & 240.00 & 23.1 & 180.00 \\
\hline \multirow[t]{4}{*}{ AN19223 } & Quartz & secondary & 5.00 & -12.30 & 4.8 & 13.70 & 144.00 & 17.3 & 175.00 \\
\hline & Quartz & primary & 5.00 & -4.60 & 1.9 & 6.20 & 302.00 & 27.2 & 195.00 \\
\hline & Calcite & secondary & 5.00 & -12.00 & 3.3 & 13.40 & 140.00 & 12.3 & 170.00 \\
\hline & Calcite & primary & 5.00 & -4.80 & 2.6 & 6.30 & 286.00 & 27.2 & 185.00 \\
\hline \multirow[t]{4}{*}{ AN19224 } & Quartz & secondary & 5.00 & -14.60 & 6.1 & 15.70 & 127.00 & 14.3 & 170.00 \\
\hline & Quartz & primary & 5.00 & -1.90 & 1.6 & 2.20 & 235.00 & 18.5 & 190.00 \\
\hline & Calcite & secondary & 5.00 & -15.60 & 5.4 & 16.00 & 143.00 & 15.5 & 175.00 \\
\hline & Calcite & primary & 5.00 & -1.80 & 1.2 & 2.10 & 226.00 & 31.7 & 160.00 \\
\hline \multirow[t]{7}{*}{ AN19226 } & Quartz & secondary & 5.00 & -15.30 & 3.8 & 15.40 & 167.00 & 38.6 & 180.00 \\
\hline & Quartz & primary & 5.00 & -5.30 & 2.6 & 6.60 & 286.00 & 24.3 & 170.00 \\
\hline & Calcite & secondary & 5.00 & -9.90 & 2.1 & 10.40 & 163.00 & 8.8 & 170.00 \\
\hline & Calcite & primary & 5.00 & -5.80 & 4.2 & 7.10 & 270.00 & 3.9 & 180.00 \\
\hline & Sphalerite & secondary & 3.00 & -10.20 & 3.3 & 11.40 & 164.00 & 10.9 & 170.00 \\
\hline & Sphalerite & primary & 5.00 & -6.30 & 1.7 & 7.80 & 267.00 & 19.8 & 185.00 \\
\hline & Wulfenite & primary & 5.00 & -3.50 & 2.1 & 5.00 & 140.00 & 23.0 & 160.00 \\
\hline \multirow[t]{4}{*}{ AN19229 } & Quartz & secondary & 5.00 & -20.00 & 4.5 & 22.00 & 88.00 & 12.0 & 166.00 \\
\hline & Quartz & primary & 5.00 & -21.90 & 5.5 & 23.80 & 175.00 & 17.6 & 180.00 \\
\hline & Calcite & secondary & 5.00 & -18.90 & 7.7 & 20.00 & 58.00 & 29.9 & 166.00 \\
\hline & Calcite & primary & 5.00 & -20.00 & 9.6 & 22.00 & 205.00 & 24.3 & 175.00 \\
\hline \multirow[t]{2}{*}{ AN19230 } & Calcite & secondary & 5.00 & -22.00 & 10.4 & 24.10 & 110.00 & 17.4 & 170.00 \\
\hline & Calcite & primary & 5.00 & -7.20 & 1.1 & 8.40 & 280.00 & 21.4 & 195.00 \\
\hline \multirow[t]{2}{*}{ AN19231 } & Calcite & secondary & 5.00 & -20.90 & 4.6 & 22.60 & 125.00 & 11.4 & 175.00 \\
\hline & Calcite & primary & 5.00 & -5.80 & 2.3 & 7.10 & 265.00 & 12.2 & 175.00 \\
\hline 8813 & Cerussite & primary & 7.00 & -5.80 & 1.8 & 7.50 & 64.00 & 16.5 & 170.00 \\
\hline \multirow[t]{2}{*}{8659} & Calcite & secondary & 5.00 & -26.60 & 7.9 & 26.40 & 146.00 & 19.2 & 170.00 \\
\hline & Calcite & primary & 5.00 & -21.70 & 6.6 & 23.70 & 182.00 & 21.3 & 200.00 \\
\hline Average & & & 5.04 & -11.60 & & 12.85 & 182.79 & & 175.61 \\
\hline
\end{tabular}

\section{Discussion}

Hydrothermal cavities, fracture fills and breccia-style systems such as those at Gross Otavi Mine and the Kombat Mine pits are tectonically controlled, epigenetic characteristics of MVT-type deposits [30]. The deposition sites are determined 


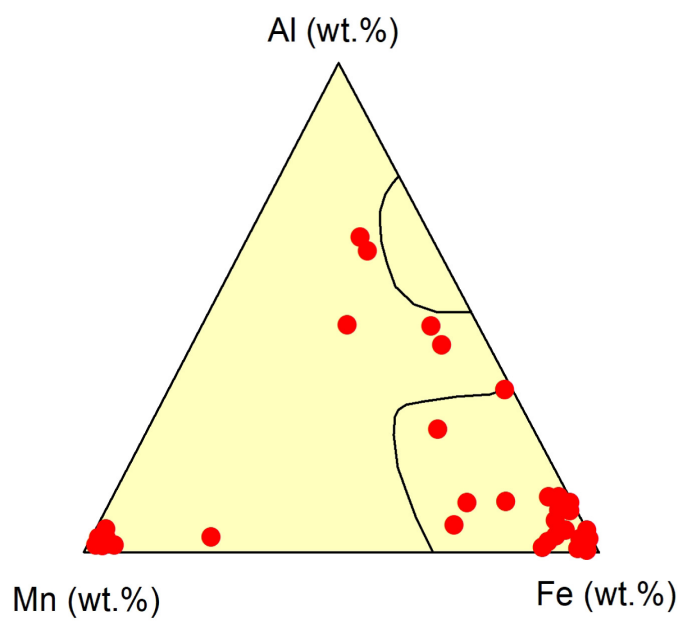

(a)

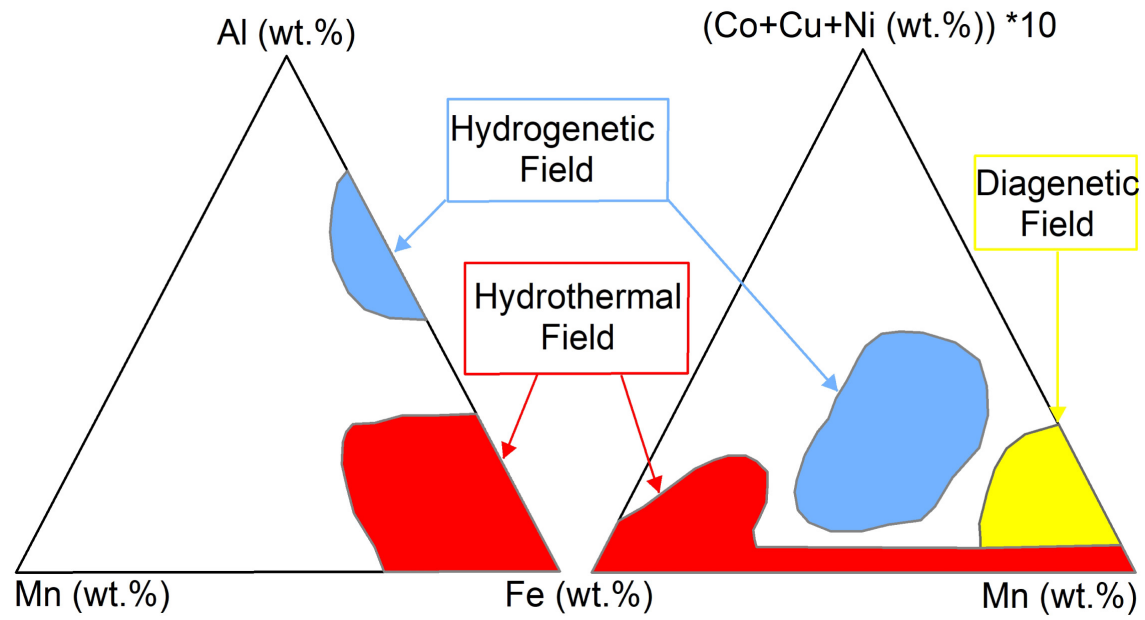

(b)

Figure 15. XRF analytical data plotted on the discriminant ternary diagrams for sedimentary rocks; (a) Kombat deposit samples compared to (b) theoretical sedimentary rocks discriminant ternary diagram for hydrogenetic, hydrothermal and diagenetic fields from modern ferromanganese deposits (after Boström, 1973) [26].

by lithological transitions, whereby the $\mathrm{Cu}-\mathrm{Pb}-\mathrm{Ag}$ ores are bound to the upper Hüttenberg dolostone and the calc-silicate rocks as a result of changes in both the vertical and lateral permeability of the rocks in the carbonate platform sequence [21] of the OML. The $\mathrm{Cu}-\mathrm{Pb}-\mathrm{Ag}$ mineralization exhibits limited, irregular primary dispersion patterns similar to an analog MVT deposit study [31]. Host rock alteration is limited and generally restricted to dolomitization characterized by smoky and white euhedral calcite crystals often surrounded by grey rims of chalcopyrite and galena (Figure 4(a); Figure 8(c), Figure 8(e), Figure $8(\mathrm{~g})$; Figure $7(\mathrm{~b})$ ) and silicification reflected by quartz veins (Figure 8(c); Figure 9 (c)) around steeply dipping, east-west striking, (F: $79^{\circ} / 195^{\circ}$ ) controlling structures, i.e. cavities, faults and shear fractures. Furthermore, relatively porous calc-silicate hosting the bedded Fe-Mn ore might have provided the metal precipitation space (aquifer) during the different hydrothermal fluid episodes (Figure 6). 


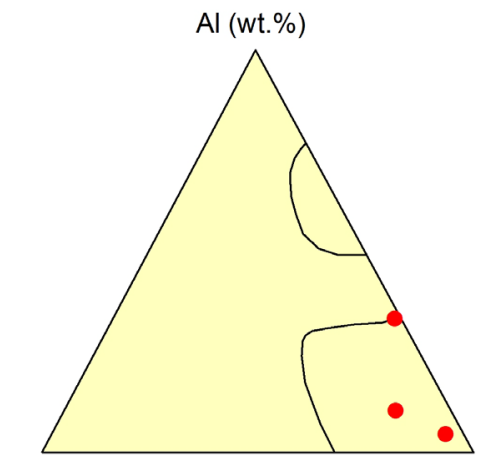

$\mathrm{Mn}$ (wt.\%)

(a)

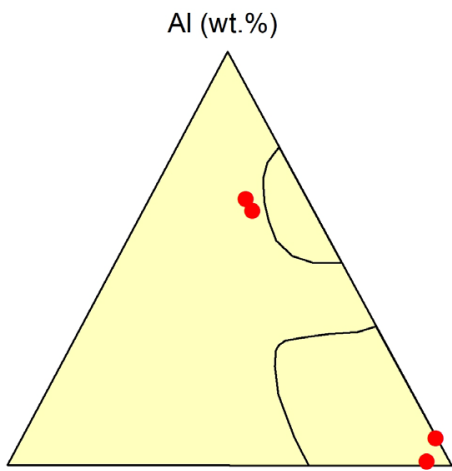

$\mathrm{Mn}(\mathrm{wt} . \%)$

$\mathrm{Fe}$ (wt.\%) Mn (wt.\%)

(c)

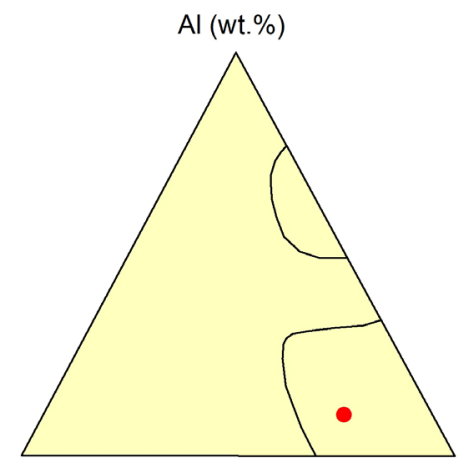

$\mathrm{Mn}(\mathrm{wt} . \%)$

Fe (wt.\%) Mn (wt.\%)

(e)

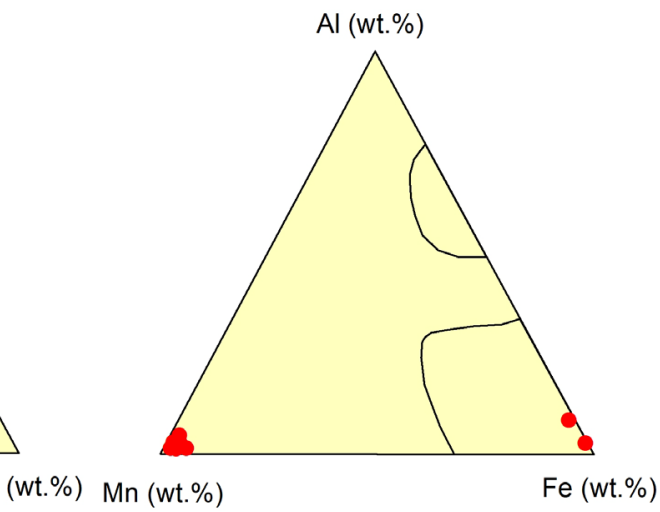

(d)

(b)

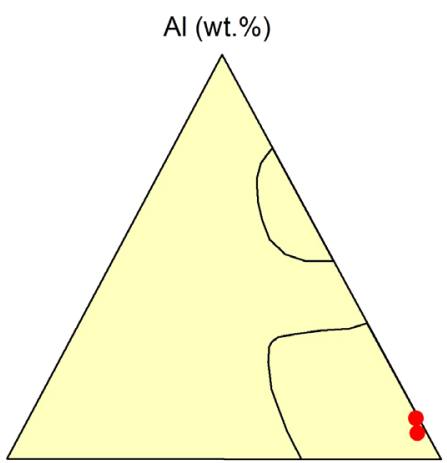

Fe (wt.\%)

(f)

Figure 16. The Fe-Al-Mn ternary diagram of hydrothermal element provenance of sedimentary rock plots for Kombat Mine sampled localities: (a) Central Pit; (b) Fe-Mn Pit; (c) OMEG pits; (d) Asis Far West; (e) 900 East pits; (f) Historic underground samples.

Phyllite represents a less permeable unit which created a trap for the metalliferous hydrothermal fluid, while its enrichment in organic matter may have provided the necessary conditions for metal precipitation.

The transmitted and reflected light microscopic study of polished and thin sections (Figure 11 and Figure 12), identified $\mathrm{Cu}-\mathrm{Pb}$ and $\mathrm{Fe}-\mathrm{Mn}$ ore minerals. The foliated, bedded samples of iron-manganese ore contain predominantly 


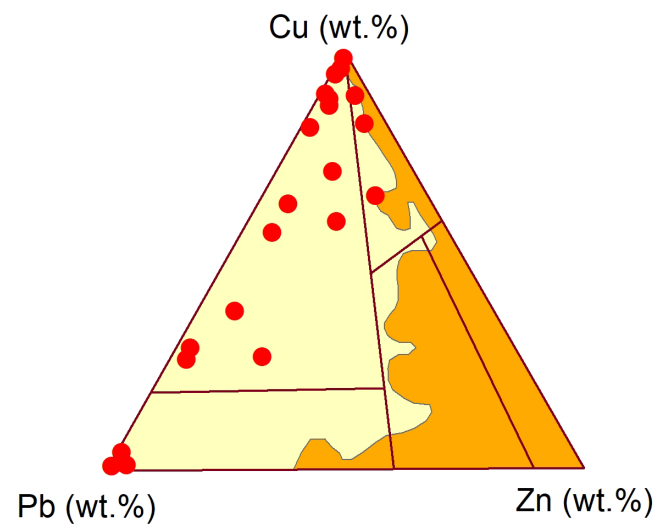

(a)
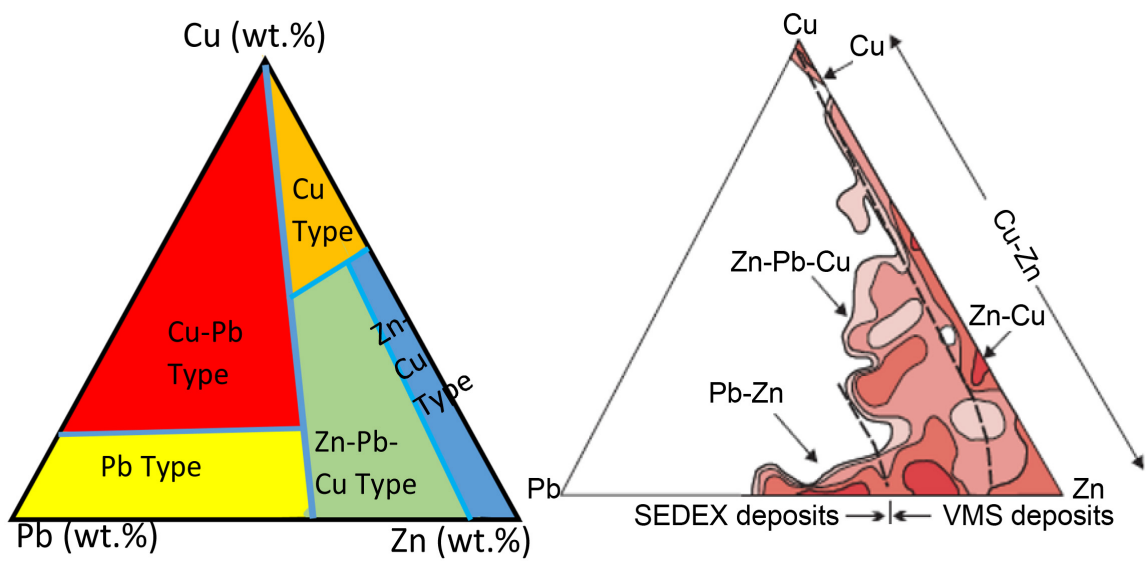

(b)

Figure 17. $\mathrm{Cu}-\mathrm{Pb}-\mathrm{Zn}$ ternary diagrams; (a) Samples from the Kombat Mine, com-pared to (b) $\mathrm{Pb}-\mathrm{Cu}-\mathrm{Zn}$ fields and SEDEX/VMS fields [23] [27].

hausmannite (Hs), magnetite (Mt), pyrite (Py), and chalcopyrite (Cp). The presence of bioturbation and relicts of beddings preserved in the calc-silicate (host rocks) indicates a syn-sedimentary deposit [32] associated with secondary hematite $(\mathrm{Hm})$ and jacobsite $(\mathrm{Jb})$ mineralization.

The copper-lead ores consist of bornite $(\mathrm{Bn})$ and chalcopyrite $(\mathrm{Cp})$ which are both being replaced by twin lamellae textures of chalcocite (Cc) and exsolution of covellite $(\mathrm{Cv})$ after bornite and chalcocite, while covellite veins have been terminated by pyrite (Py). These copper ore minerals are associated with hydrothermal dissolution and dolostone replacement features common in and about MVT deposits [33]. The hydrothermal fluid generation requires three components: 1) Brine source: possibly through evaporation of seawater in the closing Khomas Ocean and halide dissolution generated the basinal sediment brine. 2) Sulfur source: through a metamorphic breakdown of sulfate minerals and organic materials, 3) Metal source: metals may have been leached from the underlying sedimentary package through which the brines migrated [34]. During brine migration, the replacement textures observed in Figure 14 could indicate leaching of copper, zinc and tin from clays, micas and amphiboles, whereas lead originates most likely from sandstones [35]. 


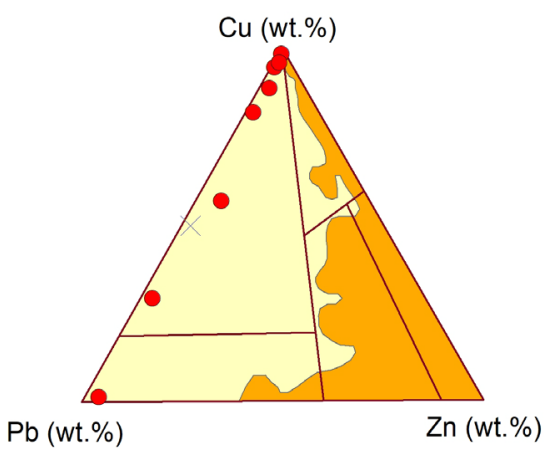

(a)

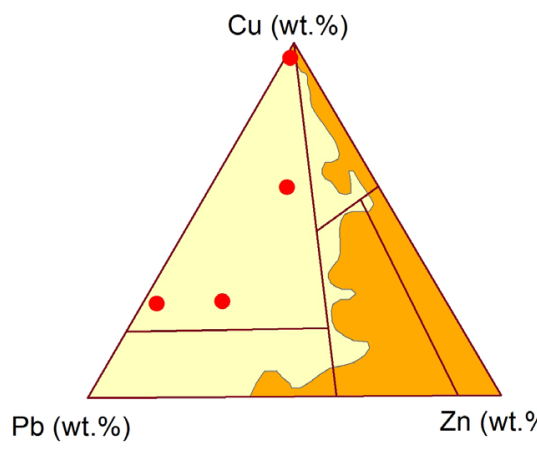

(b)

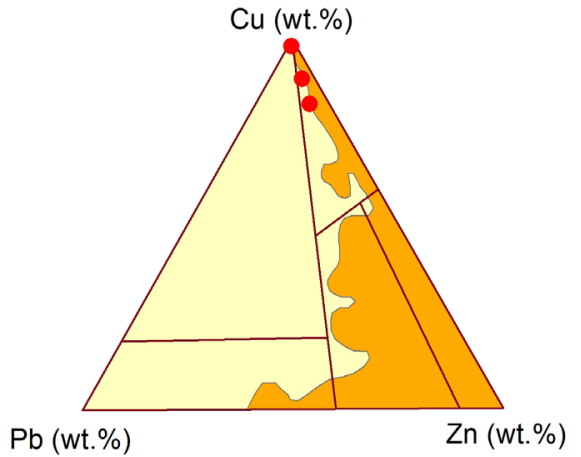

(d)

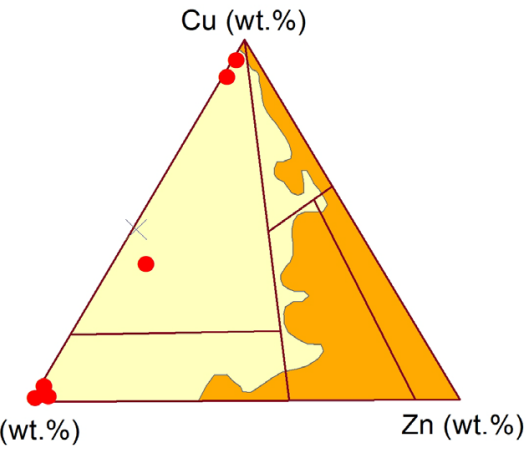

(c)

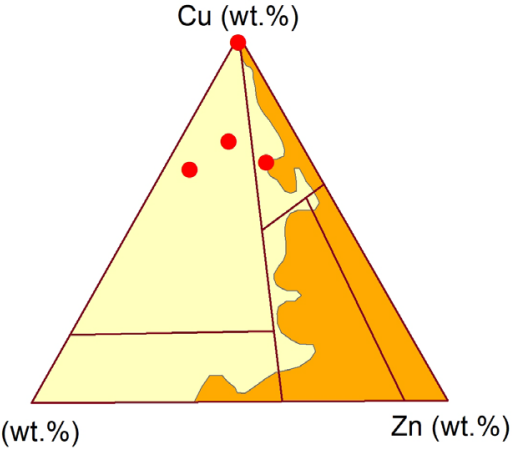

(e)

Figure 18. $\mathrm{Cu}-\mathrm{Pb}-\mathrm{Zn}$ and SEDEX/VMS Ternary diagram fields of Kombat Mine localities (a) Fe-Mn pit; (b) OMEG pits; (c) Museum; (d) Asis Far West; (e) 900 East pits.

The fluid inclusions indicate an average homogenization temperature of $183^{\circ} \mathrm{C}$, confirming a hydrothermal system, while the average salinity of 12.85 wt. \% $\mathrm{NaCl}$ equivalent points to a brine fluid as being responsible for the Kombat deposit. The brine-hydrothermal fluid system falls within the range of conditions for an MVT-type deposit [30] [33] [34]. Hence, the corrected mean temperature values on diagrams for correcting fluid inclusion homogenization temperatures [28] suggest that the Kombat deposit originated under temperatures ranging from $160^{\circ} \mathrm{C}$ to $200^{\circ} \mathrm{C}$, and salinity of 2.1 to $26.7 \mathrm{wt} \% \mathrm{NaCl}$ (Figure 22). This satisfies the typical physico-chemical conditions of MVT deposits, which originate from saline basinal metalliferous fluids at temperatures of $75^{\circ} \mathrm{C}$ to $200^{\circ} \mathrm{C}$, at crustal level or depth $\leq 1 \mathrm{~km} \mathrm{[32]} \mathrm{[35]} \mathrm{[36].}$ 

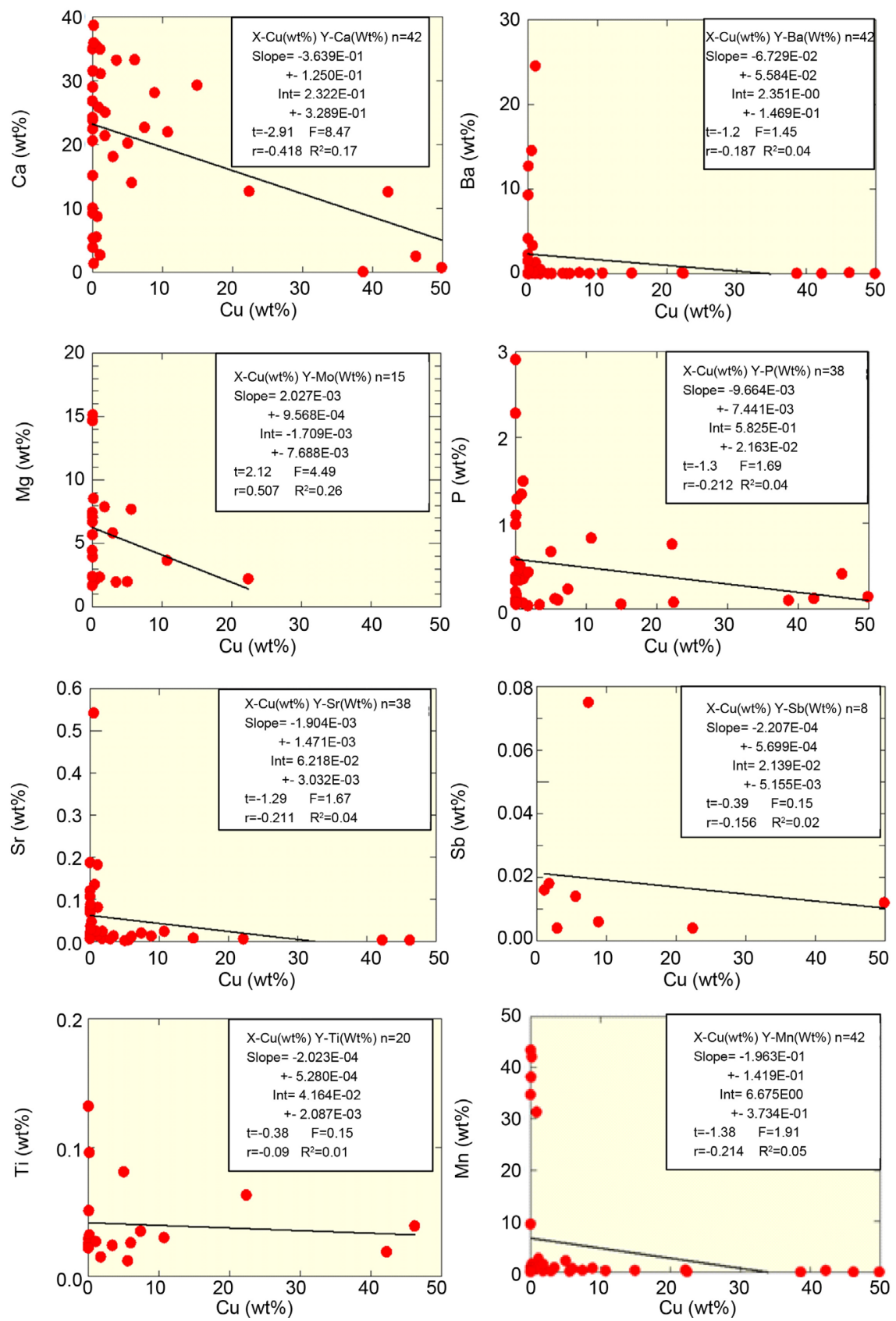

Figure 19. Elements displaying a negative Pearson correlation coefficient with copper.

On the discriminant diagram for sedimentary rocks (after Boström, 1973; Figure 15) [26] most samples from the Kombat Mine pits fall in the hydrothermal field, suggesting a hydrothermal process was predominantly responsible for the Kombat mineralization. The evaluation of individual sample localities strongly indicated hydrothermal mineralization at the Kombat Central Pit, the Asis Far West dumps and the 900 East Pits (Figure 16(a), Figure 16(d), Figure 16(e)). Dual generic fields consisting of hydrothermal and diagenetic components were revealed in the samples (Figure 16(f)), indicating that both processes took place. A diagenetic process could be associated with bedded Fe-Mn ore samples and 

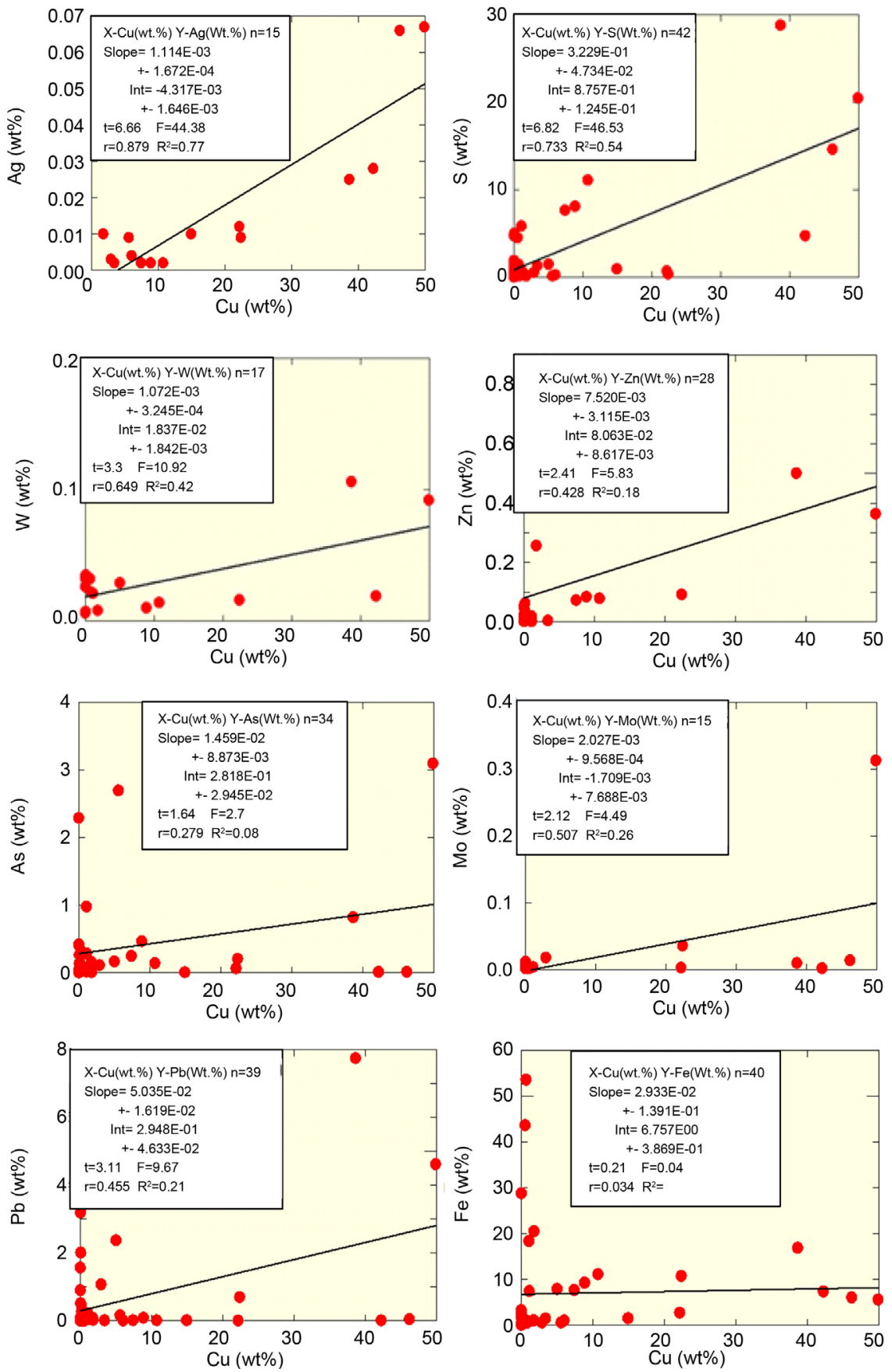

Figure 20. XRF elements showing a positive Pearson correlation coefficient with copper.

may represent deposition in a marine environment [22] [37]. Some samples from the Fe-Mn Pit and the OMEG Pits plotting in the hydrothermal-diagenetic-hydrogenetic and hydrogenetic-diagenetic mixed fields, respectively (Figure 16(b), Figure 16(c)) indicate that the hydrogenetic-diagenetic processes would be responsible for $\mathrm{Mn}, \mathrm{Cu}$ and $\mathrm{Ni}$ concentrations provided that the sedimentary package was under oxic conditions. The change to suboxic conditions would promote high $\mathrm{Mn}$ and Fe concentration [38] [39], and therefore 

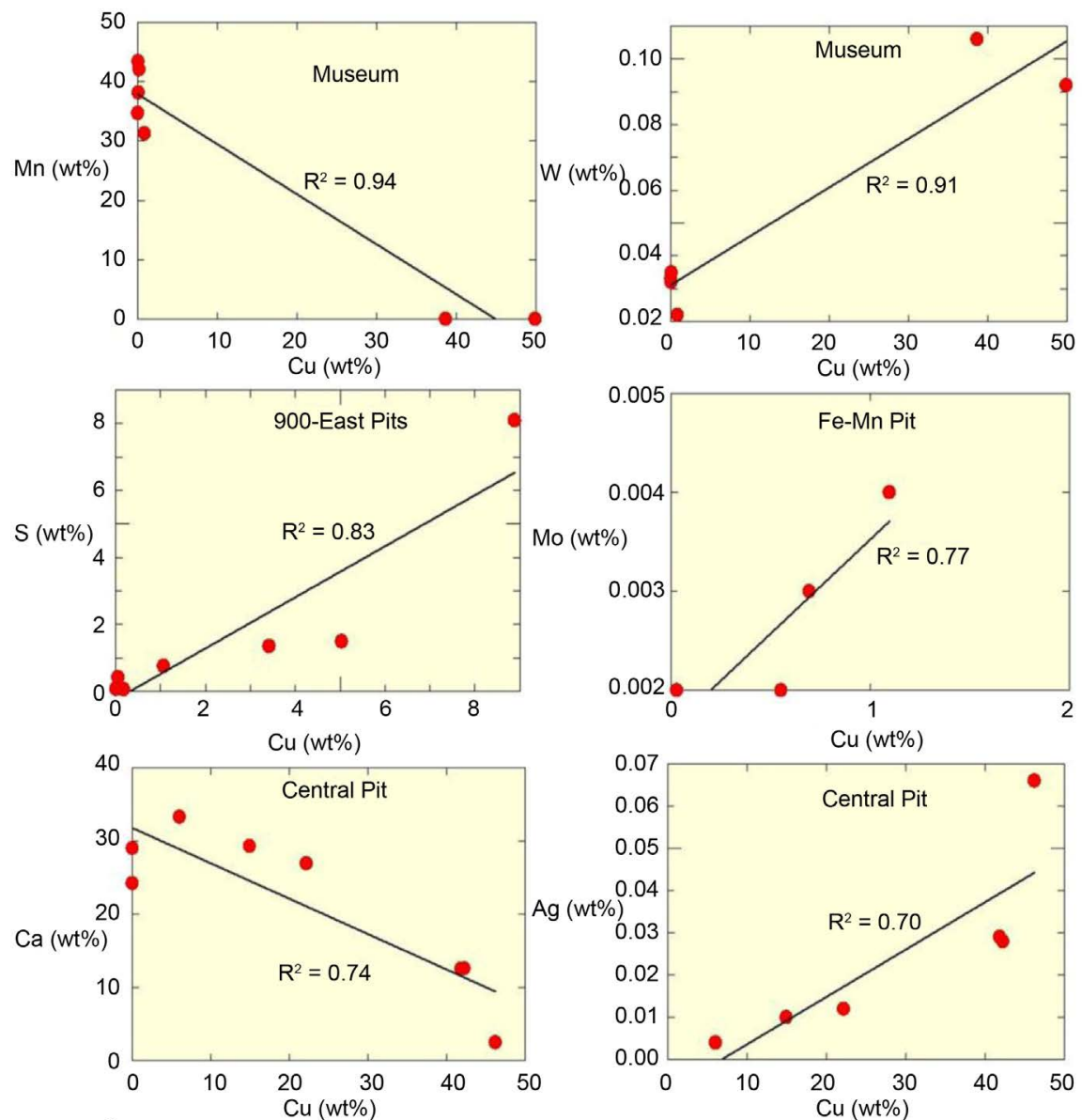

$\mathrm{Cu}(\mathrm{wt} \%)$
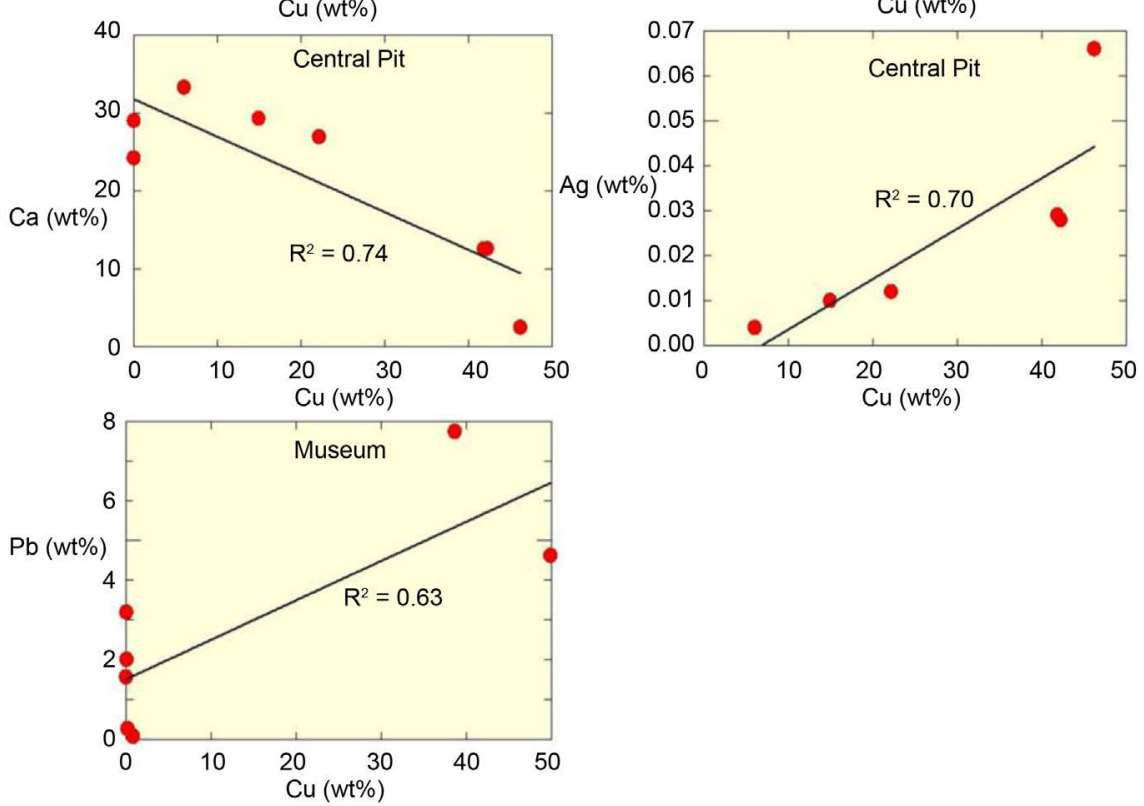

Figure 21. Binary diagrams plotting copper against various elements showing some significant correlation with copper at sample locality: Tungsten (W), Sulfur (S), Molybdenum $(\mathrm{Mo})$, Lead $(\mathrm{Pb})$ and Calcium $(\mathrm{Ca})$ Manganese $(\mathrm{Mn})$.

contribute to the stratiform Fe-Mn $(\mathrm{Cu})$ mineralization. This confirms that the stratiform Fe-Mn deposits are of syn-sedimentary marine origin, contaminated at a later stage by $\mathrm{Cu}-\mathrm{Pb}$-Ag-rich hydrothermal fluids, which agrees with the fracture zone model [7].

The VMS/SEDEX (MVT) discriminant ternary diagrams [23] [27] pinpointed a $\mathrm{Cu}-\mathrm{Pb}$-Ag type of MVT-deposit (Figure 17). However, the evaluation of sample localities indicated that the Asis Far West dumps (Figure 18(d)) fall in the $\mathrm{Cu}$-type VMS field, which is possibly due to weathering during a long period of exposure. 


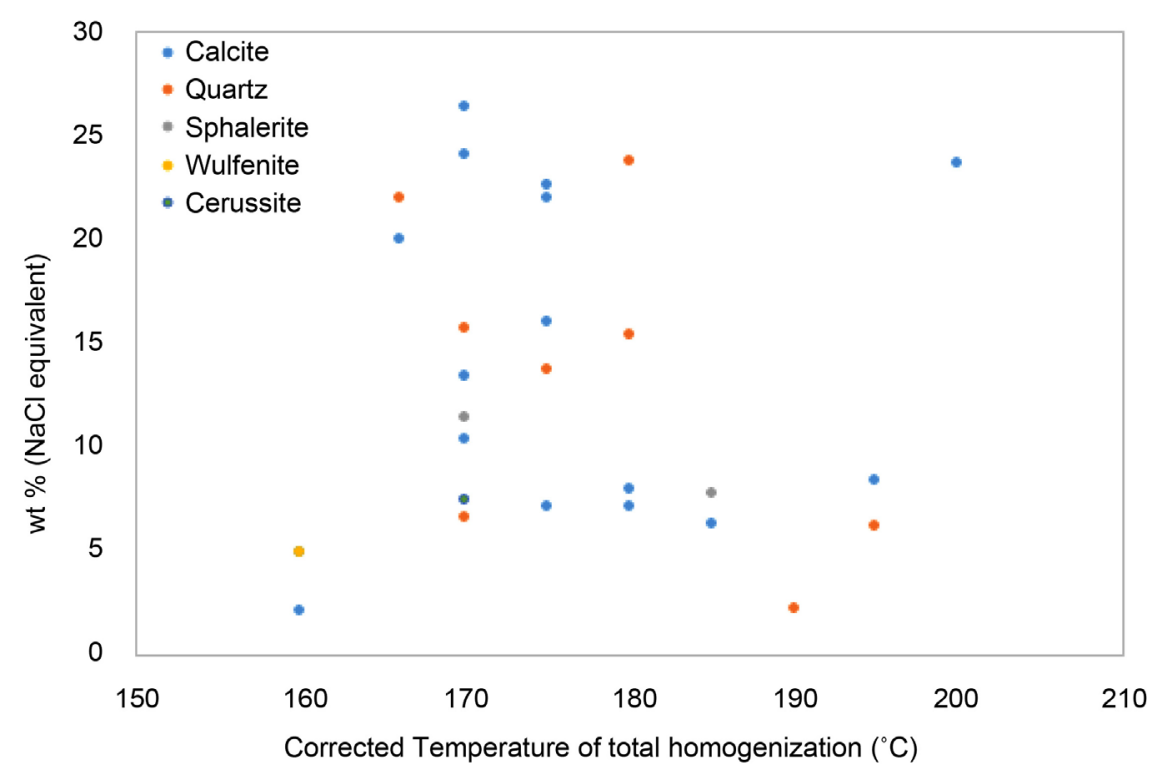

Figure 22. Salinity-corrected homogenization temperature based on diagrams for correcting fluid inclusion homogenization temperatures for fluid inclusions from various minerals [28] [29].

\subsection{Genetic of the Kombat Style Deposit}

Thus, the primary hydrothermal sulfide deposits formed by metamorphic dehydration, which supplied the sulfur and brines through tectonic pumping related to the Damara Orogeny, while the upward migration of the hydrothermal brines leached metals from the underlying package of sediments. Hence, the paragenetic sequence observed could have originated in the following metallogenic events:

1) Syn-sedimentary Fe-Mn mineralization evident by the well-preserved bedding (S0) and bioturbation (Figure 6(c)) seen in the layered Fe-Mn calc-silicate bodies (Figure 5(c)) and cross-cut by foliation (S2) (Figure 6) were deposited via diagenetic-hydrogenetic processes.

2) Penetrative fractures acted as passageways for ascending hydrothermal fluids rich in $\mathrm{Cu}, \mathrm{Pb}$ and $\mathrm{Ag}$; subsequent hydraulic fractures (veins) are filled with primary copper and lead minerals (Figure 6(b)). Silver most likely occurs as a trace element in both sulfide hosts.

3) Further deformation lead to localized brittle fracturing/faulting and remobilization of primary mineralization as well as the formation of secondary minerals along fracture cleavage/faults (S3; Figure 4(e)).

4) The first phase of alteration of secondary ore minerals (S3) lead to supergene enrichment of breccia ore minerals in zones of lower stress such as cavities and fractures (Figure 7).

5) Finally, the ore minerals are exposed to retrograde conditions during weathering, uplifting and erosion initiating a second phase of alteration and the formation of oxide ores. The paragenetic sequence is summarized in Figure 13, while Figure 23 summarizes the subsequent genetic model. 


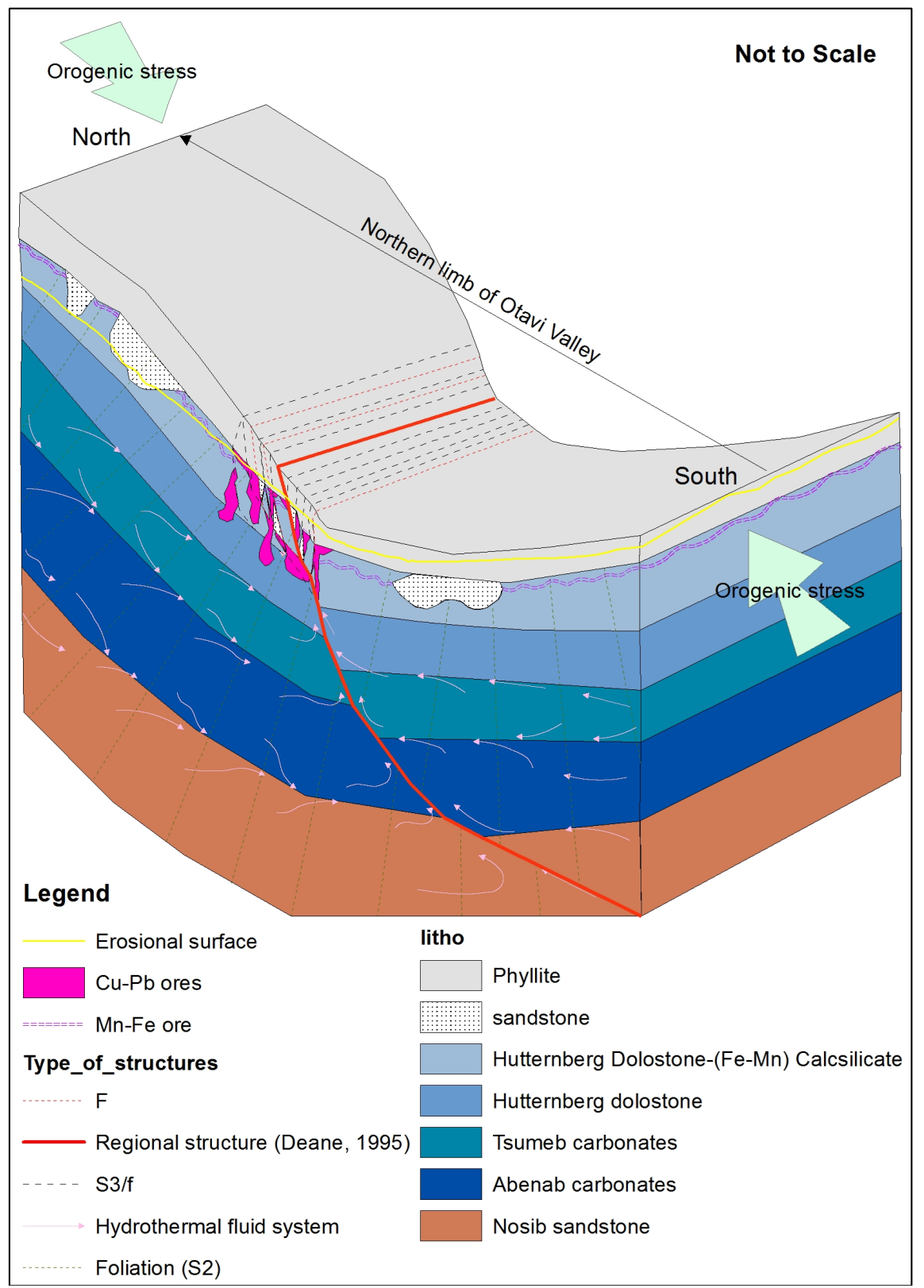

Figure 23. The Kombat Mine ore genetic model.

\subsection{Exploration Model for Kombat Style Deposit}

The Kombat Mineralization exploration model would commerce with investigating the upper Hüttenberg dolostone, and calc-silicates lithological changes of the carbonate platform sequences [33]. In the carbonate platform sequence, hydrothermal alterations such as dolomitization and silicification would be the most widespread evidence but are limited to tectonic structural control, characteristics of the MVT-type deposits [30]. The tectonic structural control features include east-west striking cavities, faults and shear fractures at an average steep dip of $79^{\circ} / 195^{\circ}$ (Figure 10). Follow up field investigation would identify the mineralogical indicators for existing ore minerals, and associated gangue miner- 
als (Table 1). On an outcrop scale, the dissolution and dolostone replacement textures associated with $\mathrm{Cu}-\mathrm{Pb}$ ores can be observed (Figure 11 and Figure 12), common in and about MVT deposits [33]. Geochemical soil and rock sampling for portable XRF analysis carried out at 1:10,000 scale or 50 - $100 \mathrm{~m}$ gridding would generate drill targets [40] using the pathfinder elements (Table 3). The pathfinder elements were calculated from the portable XRF results based on Kombat historic mine grade of $2 \% \mathrm{Cu}$ and then normalized to the current resource statement economic cut-off grade of $0.6 \% \mathrm{Cu}$ [6]. The XRD and optical sample analysis can be used to confirm the potential ore minerals that contribute to the anomalous values of portable XRF results, thus, increase the exploration target confidence.

\section{Conclusions}

The carbonate hosted Kombat-style mineralization is structurally controlled and consists of discrete vertical ore zones constrained to faults, shear fractures and karst resembling the typical characteristics of a Mississippi Valley-type (MVT) deposit. This MVT-type deposit was formed by a brine-hydrothermal fluid system with an average temperature and salinity conditions of $183^{\circ} \mathrm{C}$ and 12.85 wt. \% $\mathrm{NaCl}$ equivalent, respectively. A less permeable phyllite at the base of the Kombat Formation formed a trap for the brine-hydrothermal fluid and facilitated the deposition of $\mathrm{Cu}-\mathrm{Pb}-\mathrm{Ag}$ dominated ore within the upper Hüttenberg dolostone. Chemical control of organic-rich phyllite/shale provided reducing conditions which facilitated ore precipitation out of the hydrothermal fluids. The $\mathrm{Cu}-\mathrm{Pb}-\mathrm{Ag}$ ore is associated with syn-sedimentary bedded Fe-Mn ore hosted in the calc-silicate rocks of upper Hüttenberg with slivers of sandstone possibly belonging to the lower Kombat Formation. This Fe-Mn mineralization originated through diagenetic as well as mixed diagenetic-hydrogenetic processes within the sedimentary basin.

Geochemical exploration indicators or pathfinder elements (wt. \%) are $\mathrm{Cu}$ : 0.50; S: 0.22 Pb: 0.05; As: 0.034; Zn: 0.01; W, V, Mo: 0.002 and Ag: 0.001 based on portable XRF sample analysis that could be applied to locate potential Kombat MVT-type deposits. Mineralogical exploration indicators based on field observation, optical mineralogy and XRD prospecting include major ore minerals such as chalcopyrite, bornite, covellite, galena, and minor langite, chalcocite, sphalerite and Malachite for the MVT-type deposits. While shausmannite, hematite,

Table 3. Mineralogical exploration indicators for existing mineralization based on XRD analysis.

\begin{tabular}{|c|c|c|c|c|c|c|c|c|c|}
\hline Anomaly (XRF) & $\begin{array}{c}\mathrm{Cu} \\
\text { (wt.\%) }\end{array}$ & S (wt.\%) & $\begin{array}{c}\mathrm{Pb} \\
\text { (wt.\%) }\end{array}$ & $\begin{array}{c}\text { As } \\
\text { (wt.\%) }\end{array}$ & $\begin{array}{c}\mathrm{Zn} \\
\text { (wt.\%) }\end{array}$ & $\begin{array}{c}\mathrm{V} \\
\text { (wt.\%) }\end{array}$ & $\begin{array}{c}\text { W } \\
\text { (wt.\%) }\end{array}$ & $\begin{array}{c}\text { Mo } \\
\text { (wt.\%) }\end{array}$ & $\begin{array}{c}\mathrm{Ag} \\
\text { (wt.\%) }\end{array}$ \\
\hline Sampled ore & 7.252 & 3.229 & 0.695 & $0.71 \mathrm{~T}$ & & 0.035 & 0.030 & 0.029 & 0.017 \\
\hline Mined ore & 2.000 & 0.891 & 0.192 & 0.114 & 0.036 & 0.010 & 0.008 & 0.008 & 0.005 \\
\hline Cut-off grade & 0.500 & 0.223 & 0.048 & 0.029 & 0.009 & 0.002 & 0.002 & 0.002 & 0.001 \\
\hline
\end{tabular}


magnetite, manganite, jacobsite pyrolusite, rhodonite could indicate the presence of a syn-sedimentary, stratiform Fe-Mn deposit. Brochantite, tennantite, smithsonite, cerussite, duftite, hamatophanite, wulfenitemight occur in traces orabsent. The associated gangue minerals are predominantly dolomite $(\mathrm{Mg})$, calcite $(\mathrm{Ca})$ and quartz $(\mathrm{Si})$, with traces of anhydrite, gypsum and baryte.

The exploration model for the Kombat MVT-type deposit can be based on field mapping focusing on the steep, south-southwest dipping (F: $79^{\circ} / 195^{\circ}$ ) faults and shear fractures. On outcrop scale, one should look for recrystallization textures including euhedral calcite, quartz, tension gashes (veins), often associated with $\mathrm{Cu}-\mathrm{Pb}-\mathrm{Ag}$ ore minerals. In addition, follow up geochemical soil/rock surveys at 1:10,000 scale or 50 - $100 \mathrm{~m}$ grid spacing using a portable XRF complemented by XRD analysis could help to delineate discrete ore zones using the established mineralogical and geochemical exploration indicators. Finally, magnetic data can be used to delineate associated syn-sedimentary, stratiform Fe-Mn mineralization which is associated with the MVT-type deposit at the Kombat Mine.

\section{Acknowledgements}

Appreciation and gratitude are expressed to the following people and institutions of Namibia where the research project was registered for an MSc degree. Queens University, Canada and University of Cardiff, UK for assistance with fluid inclusion and XRD analyses; Trigon Metals (Ltd) Namibia for allowing access to the Kombat Mine sites and the Geological Survey of Namibia for assisting with XRF and petrographic analyses.

\section{Conflicts of Interest}

The authors declare no conflicts of interest regarding the publication of this paper.

\section{References}

[1] European Discovery, Development, and Early Exploitation (2015). http://www.tsumeb.com/en/history/european-discovery/

[2] Schneider, G.I.C. and Seeger, K.G. (2012) The Mineral Resources File, Geological Survey of Namibia.

[3] Killick, A.M. (1986) A Review of the Economic Geology of Northern South West Africa/Namibia. In: Anhaeusser, C.R. and Maske, S., Eds., Mineral Deposits of Southern Africa 2, Geological Society of South Africa, Johannesburg, 1709-1717.

[4] Cairncross, B. (1997) The Otavi Mountain Land Cu-Pb-Zn-V Deposits, Namibia. Mineralogical Record, 28, 109-130.

[5] Puritch, E., Routledge, R., Sutcliffe, R., Burga, D. and Hayden, A. (2014) NI-43-101 \& 43-101F1 Technical Report and Resource Estimate on the Kombat Copper Project, Grootfontein District, Otjozondjupa Region, Namibia Latitude 1942’35'S Longitude 17²'09'E UTM Zone 33K 783301 m E 7818395Ms for Kombat Copper Inc. P\&E Mining Consultants Inc., Toronto.

[6] Trigon Metals (2020) Resource Statement Update September 28, 2020. 
https://www.trigonmetals.com/2020/09/28/

[7] Kotzé, W.H. (2019) Kombat Mining Complex and Otavi Valley Mineral Deposits and Occurrences. Unpublished Report, Trigon Metals Inc., Toronto.

[8] Deane, J. (1995) The Structural Evolution of the Kombat Deposits, Otavi Mountainland, Namibia. Communications of the Geological Survey of Namibia, 10, 99-107.

[9] Pirajno, E. and Joubert, B.D. (1993) An Overview of Carbonate-Hosted Mineral Deposits in the Otavi Mountain Land, Namibia: Implications for Ore Genesis. Journal of African Earth Sciences, 16, 265-272. https://doi.org/10.1016/0899-5362(93)90048-U

[10] Hoffman, P.F., Halverson, G.P. and Schrag, D.P. (1998) A Neoproterozoic Snowball Earth. Journal of Science, 281, 1342-1346. https://doi.org/10.1126/science.281.5381.1342

[11] Hoal, K.O., Hoal, B.G., Griffin, W.L. and Armstrong, R.A. (2000) Characterization of the Age and Nature of the Lithosphere in the Tsumkwe Region, Namibia. Communications of the Geological Survey of Namibia, 12, 23-30.

[12] Minz, F. (2008) The Kombat Ore Deposit, Otavi Mountain Land (Northern Namibia). Advanced Seminars, Institute for Geology, Technical University Berg Academy, Freiberg.

[13] Miller, R. (2008) The Geology of Namibia. Volume 1, Ministry of Mines and Energy, Geological Survey, Windhoek, 690 p.

[14] Laukamp, C. (2006) Structural and Fluid System Evolution in the Otavi Mountain Land (Namibia) and Its Significance for the Genesis of Sulfide and Nonsulfide Mineralization. PhD Thesis, Universitat, Heidelberg.

[15] Trompette, R. (1997) Neoproterozoic (c. $600 \mathrm{Ma}$ ) Aggregation of Western Gondwana: A Tentative Scenario. Precambrian Research, 82, 101-112. https://doi.org/10.1016/S0301-9268(96)00045-9

[16] Melcher, F., Lodziak, J. and Vetter, U. (2004) Sulfide Mineralization in the Otavi Mountain Land, Namibia. BGR, Hannover.

[17] Kamona, A. and Günzel, A. (2007) Stratigraphy and Base Metal Mineralization in the Otavi Mountain Land, Northern Namibia-A Review and Regional Interpretation. Gondwana Research, 3, 396-413. https://doi.org/10.1016/j.gr.2006.04.014

[18] Goscombe, B., Gray D., Armstrong, R., Foster, A.D. and Vogl, J. (2005) Event Geochronology of the Pan-African Kaoko Belt, Namibia. Precambrian Research, 140, 103.e1-103.e41. https://doi.org/10.1016/j.precamres.2005.07.003

[19] Raith, M., Raase, P. and Reinhardt, J. (2012) Guide to Thin Section Microscopy. 2nd Edition, Roidestraße, Steendiek, Durban, Open Access Publication e-Book.

[20] Shepherd, T.J., Rankin, A.H. and Alderton, D.H. (1985) A Practical Guide to Fluid Inclusion Studies. Blackie, New York, Glasgow.

[21] Volesky, J., Leybourne, M., Stern, R., Peter, J.M., Layton-Matthews, D., Rice, S. and Johnson, P. (2017) Metavolcanic Host Rocks, Mineralization, and Gossans of the Shaib al Tair and Rabathan Volcanogenic Massive Sulfide Deposits of the WadiBidah Mineral District, Saudi Arabia. International Geology Review, 59, 1975-2002. https://doi.org/10.1080/00206814.2017.1307789

[22] Bailie, R. and Gutzmer, J. (2011) Age and Primary Architecture of the Copperton Zn-Cu VMS Deposit, Northern Cape Province, South Africa. Ore Geology Reviews, 39, 164-179. https://doi.org/10.1016/j.oregeorev.2011.02.001

[23] Franklin, J.M., Lydon, J.W. and Sangster, D.F. (1981) Volcanic-Associated Massive 
Sulfide Deposits. In: Skinner, B.J., Ed., Economic Geology 75 th Anniversary Volume, Society of Economic Geologists, Littleton, 485-627.

[24] Mousivanda, F., Rastadb, E., Peterc, J.M. and Maghfourib, S. (2018) Metallogeny of Volcanogenic Massive Sulfide Deposits of Iran. Ore Geology Reviews, 95, 974-1007. https://doi.org/10.1016/j.oregeorev.2018.01.011

[25] Pearson Product-Moment Correlation (2018). https://statistics.laerd.com/statistical-guides/pearson-correlation-coefficient-statisti cal-guide.php

[26] Lechte, M.A., Wallace, M.W. and Hoffmann, K. (2019) Glacio-Marine Iron Formation Deposition in a c. 700 Ma Glaciated Margin: Insights from the Chuos Formation, Namibia. School of Earth Sciences, University of Melbourne, Parkville. https://doi.org/10.1144/SP475.2

[27] Large, R.R. (1992) Australian Volcanic-Hosted Massive Sulfide Deposits: Features, Styles, and Genetic Models. Economic Geology, 87, 471-510.

https://doi.org/10.2113/gsecongeo.87.3.469

[28] Potter, R.W. (1977) Pressure Corrections for Fluid-Inclusions Homogenization Temperatures Based on the Volumetric Properties of the System NaCI-H20. Journal of. Research U.S. Geological Survey, 5, 603-607.

[29] Bussell, M.A., Alpers, C.N., Petersen, U., Shepherd, T.J., Bermudez, C. and Baxter, A.N. (1990) The Ag-Mn-Pb-Zn Vein, Replacement, and Skarn Deposits of Uchucchacua, Peru: Studies of Structure, Mineralogy, Metal Zoning, Sr Isotopes, and Fluid Inclusions. Economic Geology, 85, 1348-1383. https://doi.org/10.2113/gsecongeo.85.7.1348

[30] Paradis, S., Hannigan, P. and Dewing, K. (2007) Mississippi Valley-Type Lead-Zinc Deposits. In: Goodfellow, W.D., Ed., Mineral Deposits of Canada: A Synthesis of Major Deposit-Types, District Metallogeny, the Evolution of Geological Provinces, and Exploration Methods, Geological Association of Canada, Mineral Deposits Division, St. John's, Special Publication No. 5, 185-203.

[31] McQueen, K.G. (2015) Ore Deposit Types and Their Primary Expressions. https://www.researchgate.net/publication/267839370

[32] Baniak, G.M., Gingras, M.K., Burns, B.A. and Pemberton, S.G. (2015) Petrophysical Characterization of Bioturbated Sandstone Reservoir Facies in the Upper Jurassic Ula Formation, Norwegian North Sea, Europe. Journal of Sedimentary Research, 85, 62-81. https://doi.org/10.2110/jsr.2015.05

[33] Leach, D.L., Taylor, R.D., Fey, D.L., Diehl, S.F. and Saltus, R.W. (2010) A Deposit Model for Mississippi Valley-Type Lead-Zinc Ores, Chap. A of Mineral Deposit Models for Resource Assessment. U.S. Geological Survey Scientific Investigations Report 2010-5070-A, 52. https://doi.org/10.3133/sir20105070A

[34] Leach, D.L. and Sangster, D. (1993) Mississippi Valley-Type Lead-Zinc Deposits. In: Kirkham, R.V., Sinclair, W.D., Thorpe, R.I. and Duke, J.M., Eds., Mineral Deposit Modeling: Geological Association of Canada Special Paper 40, 289-314.

[35] Skinner, B. (1997) Hydrothermal Mineral Deposits: What We Do and Don't Know. 3rd Edition, John Wiley and Sons, New York.

[36] Giordano, T.H. and Barnes, H.L. (1981) Lead Transport in Mississippi Valley-Type Oresolutions. Economic Geology, 76, 2200-2211.

https://doi.org/10.2113/gsecongeo.76.8.2200

[37] Qiu, W.J., Zhou, M. and Liu, Z. (2018) Late Paleozoic SEDEX Deposits in South China Formed in a Carbonate Platform at the Northern Margin of Gondwana. Journal of Asian Earth Sciences, 156, 41-58. 
https://doi.org/10.1016/j.jseaes.2018.01.006

[38] Calvert, S.E. and Piper, D.Z. (1984) Geochemistry of Ferromanganese Nodules from DOMES Site A, Northern Equatorial Pacific: Multiple Diagenetic Metal Source in the Deep Sea. Geochimica et Cosmochimica Acta, 48, 1913-1928. https://doi.org/10.1016/0016-7037(84)90374-0

[39] Schultz, H.D. (2006) Quantification of Early Diagenesis: Dissolved Constituents in Pore Water and Signals in the Solid Phase. In: Schultz, H.D. and Zabel, M., Eds., Marine Geochemistry, 2nd Edition, Springer, Heidelberg, 75-77.

[40] Hao, D. and Jun, W. (2018) Applied Geophysics: Electrical and Electromagnetic Methods. Unpublished Lecture Series. Windhoek. 